Özdemir, O. (2020). Türkçe eğitiminde geliştirilmesi gereken bir üst düzey düşünme becerisi: Analitik düşünme. Ana Dili Eğitimi Dergisi, 8(3), 950-971.

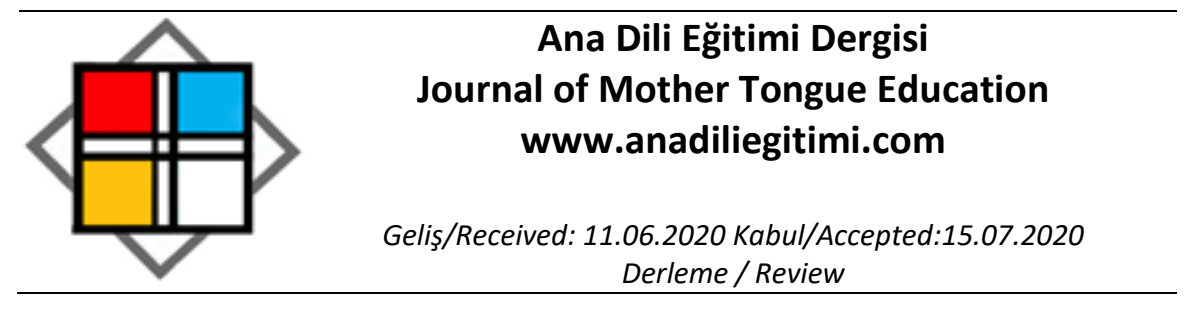

\title{
Türkçe Eğitiminde Geliştirilmesi Gereken Bir Üst Düzey Düşünme Becerisi: Analitik Düşünme
}

\author{
Osman ÖZDEMIR*
}

Öz

Bu çalışmanın amacı, üst düzey düşünme becerilerinden biri olan analitik düşünmenin Türkçe eğitiminin temel dil becerileriyle ilişkisini ortaya koymak ve bu konuda teorik bir çerçeve oluşturmaktır. Türkçe öğretiminde üst düzey düşünme becerilerinin kazandııılmasında yaşanan problemler, alanyazındaki çalışmalar ve PISA sınavlarındaki üst düzey düşünebilen başarılı öğrenci oranının azlığı ile açıkça görülebilmektedir. Bu doğrultuda, derleme makale formatında hazırlanan bu çalışmada, nitel araştırma desenlerinden temel nitel araştırma deseni kullanılmıştır. Analiz birimi olarak yenilenmiş Bloom taksonomisinin analiz basamağının alt boyutları olan ayırt etme, organize etme ve ilişkilendirme / dayandırma boyutları kullanılmış ve buna göre temel dil becerileri ile analitik düşünme becerileri ilişkilendirilmiştir. Ardından bu üç başlğa yönelik etkinlik örnek olarak hazırlanan etkinlik ya da sorular yine aynı doğrultuda ele alınmıştır. Sonuç olarak analitik düşünme becerisinin eğitim yoluyla geliştirilebileceği, sentez ve değerlendirme gibi daha üst basamaklarındaki düşünme becerilerinin geliştirilmesi için ön hazırlığı teşkil ettiği ortaya koyularak bu konuda yapılabilecek yeni araştırmalar için öneriler sunulmuştur.

Anahtar Kelimeler: Analitik düşünme, üst düzey düşünme becerileri, temel dil becerileri, Türkçe eğitimi.

\section{A Higher Order Thinking Skill to be Developed in Turkish Language Teaching: Analytical Thinking}

\begin{abstract}
This study aims to determine the relationship between analytical thinking, which is one of the higher order thinking skills, with the main language skills of Turkish language education and to form a theoretical framework in this regard. The problems experienced in teaching higher-order thinking skills in Turkey, can be clearly seen with many studies in literature and with the low percentage of successful students taking PISA reading exams. Accordingly, in this study, which was prepared in the form of a review article, the basic qualitative research method was used. As a unit of analysis, differentiating, organizing and connecting/relating dimensions, which are the sub-dimensions of the analysis level of the renewed Bloom taxonomy, were used and basic language skills and analytical thinking skills were associated, accordingly. Then, the activities and questions prepared as an example for these three sub-titles were analyzed in the same direction. As a result, analytical thinking skills were defined as a skill which can be developed through language education. This skill is also preliminary preparation for developing higher-order thinking skills such as evaluation and creation. At the end of this study, some suggestions for further research on this subject were presented.
\end{abstract}

Keywords: Analytical thinking, higher-order thinking, main language skills, Turkish language teaching.

\footnotetext{
* Dr. Öğr. Üyesi, İstanbul Sabahattin Zaim Üniversitesi Eğitim Fakültesi, Türkçe Eğitimi Ana Bilim Dalı, İstanbul, osman.ozdemir@izu.edu.tr, ORCID: https://orcid.org/0000-0003-0627-0768
} 


\section{Giriş}

Türkçe eğitiminin temel amaçlarından biri, üst düzey düşünme becerilerinin geliştirilmesidir. Nitekim şu an yürürlükte olan 2018 Türkçe Öğretim Programı'nın özel amaçlarından birinin öğrencilerin üst düzey bilişsel becerilerinin geliştirilmesine katkı sağlamak olduğu belirtilmektedir (MEB, 2019). Düşünme becerilerinin gelişimine yönelik verilecek eğitimin temel dayanaklarından birinin, ana dilinde beceri geliştirmeye yönelik dersler olduğunu söylemek yanlı̧ olmaz. Bunun temel sebebi ise dilin, düşünme eyleminin temel aracı ve iletim yöntemi olmasıdır. Bu noktada düşünce ve dilin birbirini içeren ve destekleyen iki unsur olduğu söylenebilir. Dilin olanaklarını kullanarak düşünce oluşturulur ki burada dil düşünceye kaynaklık etmektedir. Bunun yanında günlük hayatta temel dil becerilerini kullanarak ifade edilen söz, yazı veya görseller ise aslında bir düşüncenin ürünüdür ki burada da düşünce dile kaynaklık etmektedir. (Özdemir, 2019). Dolayısıyla öğrencilerin üst düzey düşünme becerilerinin gelişimi için Türkçe dersinin temel ögeleri (metinler, etkinlikler, ölçme değerlendirme faaliyetleri... vb.), başvurulması gereken öncelikli unsurlardır.

Genel olarak alan yazında Bloom taksonomisinin son üç basamağı olan analiz, sentez ve değerlendirme becerileri, bu üst düzey düşünme becerileri olarak belirtilmektedir (Çakır ve Senemoğlu 2011; Kang, 1999). Ancak bazı çalışmalarda bunlara ek olarak problem çözme, mantık, akıl yürütme, yansıtıcı düşünme, metabilişsel düşünme, lateral düşünme, altı şapkalı düşünme, tümevarımsaltümdengelimsel düşünme gibi farklı başlıklarda da bu beceriler tanımlanmaktadır (Brookhart, 2010; Güneş, 2012; Kapanadze, 2019). Üst düzey düşünme becerileri içerisinde yer alan becerilerden analiz etme / analitik düşünme becerisi; bütünün parçalara ayrılması, parçanın bütün ile ilişkisinin ve parçaların birbiri ile ilişkisinin kavranması olarak tanımlanmaktadır (Anderson ve Krahtwol. 2001; Amer, 2005; Bloom, vd., 1956; Brookhart, 2010). Analitik düşünme, bütüncül düşünmenin tersine, bütünü parçalarına ayırıp bu parçaları önce ayrı ayrı ele almayı ve daha sonra sistemin çalışmasını sağlamak için parçaların nasıl etkileşimde bulunduğuna bakmayı ifade eder (Güneş, 2012). Dolayısıyla analitik düşünme eğiliminde olan kişi, büyük bir sorunu daha basit parçalara bölüp bu bölünmüş parçalara çözümler üreterek asıl sorunu çözmeye çalışacaktır.

Platon'un tümdengelim yöntemini kullanarak mantıksal çıkarımlar yapmasıyla felsefi temellerinin oluştuğu belirtilen analitik düşünme, Descartes'in felsefesinde de önemli bir yer tutmaktadır (Çakır ve Senemoğlu, 2016). Nitekim Descartes (2014: 50-51) bunu "Bir sorunun ne olduğunu tam olarak anladığımız zaman, onu tüm yüzeysel kavramlardan kurtarmak, en basite indirgemek, sıralama yoluyla mümkün olduğunca bölümlere ayırmak gerekir." şeklinde ifade etmektedir. Nitekim alanyazındaki birçok çalışmada da (Behn ve Vaupel (1976); Markman, Lindberg, Kray ve Galinsky, 2007; Ohlsson, 2011; Robbins, 2011; Stice, 2007; Weisberg, 2015) analitik düşünme ile problem çözme becerisinin bir arada ele alınmasının nedeni, analitik düşünmenin problem çözmede bir metot olarak kullanılmasıdır. Weisberg (2015)'e göre problem çözme süreci iki şekilde gerçekleşmektedir. Bunlardan ilki içsel (insight) problem çözmedir. Bu çözüm şekli bir probleme yönelik içsel bir anlayış ve iç görünün oluşması ile aniden ortaya çıkan çözüm şeklidir. İkincisi ise yeni bir problemin çözümünde eldeki ile benzer olan tanıdık bir problemden çözümün aktarılmadır. Bu çözüm ise analize ve analitik düşünmeye dayanmaktadır. Çünkü bu çözüm yolunda, mevcut problem durumundaki alt ögeleri belirlemek, çözümle ilgili olanları olmayanlardan ayırt etmek ve önceki problem durumundaki çözüm ögeleri ile ilişkilendirmek gerekmektedir.

Genel olarak üst düzey düşünme becerileri, özelde analitik düşünme becerileri Türkçe öğretim programında yer alan ve öğrencilerin günlük hayatta karşılaşabilecekleri durumlarda ihtiyaç duyabilecekleri bir beceri olmasının yanında, akademik hayatlarında da kullanmaları gereken bir beceridir. Ancak Türkçe öğretim programının kazanımlarına bakıldığında üst düzey düşünme becerilerine yeteri kadar yer verilmediği belirtilmektedir. Bu çalışmalarda programdaki analiz basamağını destekleyen kazanımların \%8 ile \%13 arasında olduğu tespit edilmiştir (Büyükalan-Filiz ve Yıldırım, 2019; Çerçi, 2018). Aynı şekilde ortaokul Türkçe ders kitaplarının içeriğine bakıldığında; Durukan ve Demir (2017) tüm becerilerdeki etkinliklerin, Eroğlu (2019) tüm metin altı sorularının, Sezgin ve Gedikoğlu Özilhan (2019) metne dayalı anlama sorularının yine üst düzey düşünme becerilerine hitap etmediğini ifade etmektedir. 
Analitik düşünme becerisine yönelik öğrencilerin durumunu ele almak için bakılabilecek en doğrulanabilir verilerin PISA okuma sınavı ile elde edilebileceği düşünülmektedir. Bunun iki temel sebebi vardır: İlk olarak PISA sınavının okuma taksonomisine bakıldığında, üst düzeydeki beceri tanımlarında büyük ölçüde analitik düşünmeye yer vermektedir. Tablo 1 'de analitik düşünme ile ilişkilendirilebilecek beceri tanımları 4., 5. ve 6. düzeylerde yer almaktadır. Ancak Türk öğrencilerin genel olarak toplandıkları başarı düzeylerinin ise 1a., 2. ve 3. düzeyler olduğu görülmektedir.

Tablo 1.

Son yapılan 2018 PISA sınavı okuma becerileri taksonomisi

Okuma becerileri yeterlik ölçeğindeki düzeylerin içeriği

6.

Bu düzeydeki öğrenciler, istenilen bilginin metin içerisinde saklı olduğu uzun ve soyut metinleri anlayabilirler. Bilginin nasıl kullanılacağına karar vermek için çeşitli ölçütler kullanabilir, bilgilerin benzer ve zıt yönlerini karşılaştırabilir ve bu bilgileri bir araya getirebilirler. Dış ölçütler kullanarak metnin kaynağı hakkında derinlemesine düşünebilirler. Bilginin kaynağı ve geçerliğiyle ilgili ipuçları aracılığıyla metinler arasındaki uyumsuzlukları belirleyebilirler. Metinler arası tutarsızlıkları çözebilir, farklı metinlerdeki bilgilerin benzer ve zıt yönlerini karşılaştırabilirler.

5.

Bu düzeydeki öğrenciler, uzun metinlerde konuyla ilgili saklı bilgileri bularak bu metinleri kavrayabilirler. Kapsamlı metinlere yönelik derin bir anlayış göstererek farklı akıl yürütme yöntemlerini kullanabilirler. Çeşitli metin veya kaynaklarda yer alan bilgiler ile soru arasında ilişkiyi kurarak soruları cevaplayabilirler. Belli bilgilerden yola çıkarak hipotezler oluşturabilir ya da var olan hipotezlere ilişkin değerlendirme yapabilirler. Karışık ve soyut ifadelerin olduğu durumlarda gerçek ile algı arasındaki ayrımı yapabilirler. Çeşitli ipuçlarından yola çıkarak verilen bilginin kaynağının ya da içeriğinin objektifliğini değerlendirebilirler.

4.

$\mathrm{Bu}$ düzeydeki öğrenciler, bir veya birden çok metinde yer alan uzun paragrafları anlayabilirler. Metni bir bütün olarak ele alarak dile dayalı farklılıkları yorumlayabilirler. Çeşitli kaynaklardan yola çıkarak farklı bakış açılarını karşılaştırabilir ve sonuç çıkarabilirler. Metne yerleştirilmiş bilgileri arayabilir, bu bilgilere ulaşabilir ve bir araya getirebilirler. Bilginin uygunluğunu değerlendirmek için çıkarımlar yapabilirler. Metnin dikkat çekici özelliklerinden yola çıkarak yazarların kendi fikirlerini aktarmak için kullandıkları ifadeleri belirleyebilirler. Çeşitli metinlerde açıkça ifade edilen iddiaları kıyaslayabilir ve kriterlere göre bilgi kaynağının güvenirliğini değerlendirebilirler.

3.

Bu düzeydeki öğrenciler, açık şekilde sunulmadığı durumlarda da metnin genel anlamını ifade edilebilirler. Bilgileri derleyebilir, basit ve ileri düzeyde çıkarımlar yapabilirler. Çok uzun olmayan metinlerin ana düşüncesini belirlemek, ilişkileri anlamak, bir kelime veya ifadenin anlamını çıkarmak için metnin farklı bölümlerindeki bilgileri bir araya getirebilirler. Çeşitli kriterlere göre elde edilen bilgiler arasındaki ilişkileri anlayabilirler. Bu düzeydeki öğrenciler, bir veya birkaç metin üzerine derinlemesine düşünebilirler. Sunulan bilgilerden yola çıkarak farklı yazarların bakış açılarını kıyaslayabilirler.

2.

Bu düzeydeki öğrenciler, orta uzunluktaki metinlerin ana düşüncesini belirleyebilirler. Gerekli bilgilerin açıkça verilmediği durumlarda metnin belirli bir bölümündeki ilişkileri anlayabilir ve bir bölümünden anlam çıkarabilirler. Birkaç sayfalık metin içerisinde konu ile ilgili sayfayı bulabilir ve konuyla ilgili düzeylerini artırabilirler. Gerekli bilgilerin açıkça verildiği durumlarda orta uzunluktaki 
metinlerin genel amacı ve belirli detaylar üzerine derinlemesine düşünebilirler. İddiaları karşılaştırabilir ve bu iddiaları destekleyen düşünceleri belirleyebilirler.

1 a.

Bu düzeydeki öğrenciler, cümlelerin veya kısa paragrafların gerçek anlamını kavrayabilirler. Aşina oldukları konularda yazılmış metinlerin ana fikrini ve yazarın amacını anlayabilirler. Metinde verilen bilgiler arasında veya metinde verilen bir bilgiler ile kendi sahip oldukları bilgiler arasında basit bağlantılar kurabilirler. Birkaç sayfalık metinler içinde ilgili sayfayı bulabilir ve kısa metinlerde yer alan bir bilgilere ulaşabilirler. Bilgilerin açıkça sunulması durumunda metinlerin genel amacı ve nispeten önemli bilgileri üzerinde (metnin ana fikri gibi) derinlemesine düşünebilir.

1b. Bu düzeydeki öğrenciler, basit cümlelerin gerçek anlamlarını değerlendirebilirler. Soru ve/veya metindeki bilgiler arasında basit bağlantılar kurarak metinlerin gerçek anlamını yorumlayabilirler. Tek bir cümle, kısa bir metin veya basit bir listede istenen bilgileri tarayabilir ve bulabilirler. Açık bir şekilde istendiğinde birkaç sayfalık metin içerisinde ilgili sayfayı bulabilirler.

1c Bu düzeydeki öğrenciler, kısa ve basit cümlelerin anlamını kavrayabilirler. Sınırlı bir süre içinde açık, basit ve somut amaçlar için okuma yapabilirler.

Kaynak: (MEB, 2019)

İkinci olarak ise, genel olarak üst düzey düşünme becerileri, özelde ise analitik düşünme becerileri açısından PISA sınavının tüm dünya ile karşılaştırılmalı bir sonuç ortaya koymasıdır. Böylece ülkelerin öğrenci başarı düzeyi açısından diğer ülkeler arasındaki yeri görülebilmektedir. Buna göre katılan ülkelerin sayısı değişse de Türkiye'nin sıralamasının benzer aralıklarda kaldığı görülmektedir. PISA okuma testinde Türkiye'nin yıllara göre sıralaması, Tablo 2'de görülebileceği şekilde gerçekleşmiştir.

Tablo 2.

Yıllara göre Türkiye'nin PISA okuma testindeki sıralaması

\begin{tabular}{cccccc}
\hline 2003 & 2006 & 2009 & 2012 & 2015 & 2018 \\
\hline 35. & 37. & 39. & 42. & 50. & 40. \\
\hline
\end{tabular}

Kaynak: (MEB, 2005; MEB, 2010a; MEB, 2010b; MEB, 2015 ; MEB, 2016; MEB, 2019)

Belirtilen PISA raporları genel manada sıkça tartışılmaktadır. Ancak bu raporlara kümülatif başarı sıralamasından ziyade, bir de üst düzey düşünebilen öğrenci oranı açısından bakılması gerekmektedir. PISA okuma testlerinde Türk öğrencilerin aldıkları düşük puanlara bakıldığında, bu becerilerin yeteri kadar gelişmediği görülmektedir. Oysa PISA, öğrencilerin bilgi ve becerilerini günlük hayat problemlerine nasıl aktarabildikleri noktasına odaklanmaktadır. Böylece PISA'da, ülkelerin önümüzdeki 10 yıldan sonra ekonomisinde ve yönetiminde yer alacak öğrencilerin kendileri için gerekli olan becerilere ne düzeyde sahip oldukları ve bunu gerçek hayattaki durumlara ne ölçüde aktarabildikleri ölçülmektedir. Türk öğrencilerin PISA'da başarısız olmalarının önemli nedenlerinden birinin test tekniğine dayalı eğitim sistemi olduğu düşünülmektedir. Dolayısıyla bu çalışmada ortaya koyulan etkinlik önerileri ile analitik düşünme becerilerinin nasıl geliştirilebileceği konusunun ele alınması ayrı bir önem arz etmektedir. Bunun yanında ana dilinde üst düzey düşünmeyi gerçekleştiremeyen öğrencinin matematik ve fen gibi alanlarda da başarılı olamayacağı gerçeğinden yola çıkarak ana dildeki okuma becerisine yönelik yapılacak olumlu faaliyetlerin diğer akademik alanlara da olumlu bir şekilde sirayet edeceği sonucuna ulaşılabilir. 
Genel olarak üst düzey düşünme becerilerin sadece başarılı öğrenciler için uygun bir tanımlama olduğu düşünülür. Ancak Zohar ve Dori (2003) bunun doğru olmadığını belirterek özellikle öğretmenlerin bu tarz bir inanışa sahip olmalarının eğitim süreçlerini kötü etkilediğini belirtmektedir. Zaten 2018 PISA sınavının okuma becerileri bölümünün düzeylere göre dağııımına bakıldığında eğitim yoluyla üst düzey düşünme becerilerinin geliştirilebileceği görülebilmektedir. Nitekim Tablo 3 'te Türkiye'nin PISA okuma başarısının yıllara ve PISA'nın taksonomik düzeylerine göre ayrılmış profili görülmektedir. Tablonun son satırında ise karşılaştırma yapmak için 2018 yılı OECD ülkelerinin okuma becerilerinde ortalama dağııımları verilmiştir.

Tablo 3.

Türk öğrencilerin PISA okuma testlerindeki başarı düzeyi dağılımları

\begin{tabular}{lcccccccc}
\hline Yıllar & $\begin{array}{c}1 \mathrm{~b} \\
\text { düzeyi } \\
\text { altı } \%\end{array}$ & $\begin{array}{c}1 \mathrm{~b} \\
\text { düzeyi } \\
\%\end{array}$ & $\begin{array}{c}1 \mathrm{a} \\
\text { düzeyi } \\
\%\end{array}$ & $\begin{array}{c}2 . \\
\text { düzey } \\
\%\end{array}$ & $\begin{array}{c}3 \text { düzey } \\
\%\end{array}$ & $\begin{array}{c}4 . \\
\text { düzey } \\
\%\end{array}$ & $\begin{array}{c}5 . \\
\text { düzey } \\
\%\end{array}$ & $\begin{array}{c}6 . \\
\text { düzey } \\
\%\end{array}$ \\
\hline 2003 & & 12,5 & 24,5 & 30,9 & 20,8 & 7,7 & 3,8 \\
\hline 2006 & & 10,8 & 21,4 & 31,0 & 24,5 & 10,3 & 2,1 \\
\hline 2009 & 0,8 & 5,6 & 18,1 & 32,2 & 29,1 & 12,4 & 1,8 & 0 \\
\hline 2012 & 0,6 & 4,5 & 16,6 & 30,8 & 28,7 & 14,5 & 4,1 & 0,3 \\
\hline 2015 & & 13,6 & 26,8 & 32,6 & 21,1 & 5,7 & 0,6 & 0 \\
\hline 2018 & 0,7 & 6,3 & 19,1 & 30,2 & 26,9 & 13,5 & 3,1 & 0,2 \\
\hline $\begin{array}{l}\text { Oecd } \\
2018 \text { Ort. }\end{array}$ & 1,4 & 6,2 & 15 & 23,8 & 26,1 & 18,8 & 7,3 & 1,3 \\
\hline
\end{tabular}

Kaynak: (MEB, 2005; MEB, 2010a; MEB, 2010b; MEB, 2015; MEB, 2016; MEB, 2019)

Tablo 3'e bakıldığında 15 yıllık bir süreç içinde PISA okuma sınavlarında üst düzey beceriye sahip olan öğrenci oranının azlığı dikkat çekmektedir. Nitekim 2018 PISA okuma sınavında üst düzey düşünme becerisine sahip öğrenci oranının OECD ortalaması 5. ve 6. düzey toplamı \%8,6 iken Türkiye'nin oranı \%3,3'tür (MEB, 2019). Öte yandan okul sıralarına gelen çocuklara genel olarak bakıldığında üstün zekalı çocukların \%2,5- \%3; bunlara üstün yetenekli çocuklar dâhil edildiğinde ise \%5 civarında olduğu belirtilmektedir (Ataman, 2012; Kabacaoğlu, 2009). Yani okul sıralarına gelen her yüz çocuktan yaklaşık 4'ü üst düzey becerilere sahip iken son 15 yıllık PISA okuma sınavı sonuçlarında üst düzey basamaklarda ortalama \%2,7 civarında kalmamız, üst düzey düşünebilen çocukların oranında bir artış sağlanamadığı, dahası, halihazırda bu kapasiteye sahip olan çocukların bir kısmının ortalama düzeye düştüğü görülmektedir. Oysa OECD 2018 ortalamasına bakıldığında bu oran \% 8,6'dır. Yani OECD ülkeleri verdikleri eğitimle ortalama olarak \%4'lük üst düzey beceriye sahip öğrencinin yanında bir o kadar da üst düzey düşünebilen öğrenci yetiştirebilmektedir. Nitekim üst düzey düşünmenin eğitimle desteklenerek geliştirilebilen bir olgu olması (Zohar ve Dori, 2003) aslında eğitim sisteminde sunulan derslerin içeriğinin, özellikle de temel dil becerisi dersi olan Türkçe dersi içeriğinin ele alınması gerekliliğini ortaya koymaktadır.

Ana dilinde okuma alanına düşünme becerileri açısından bakıldığında, PISA sınavlarında Türkiye'deki öğrencilerin ağırlıklı olarak $1 \mathrm{a}, 2$ ve 3 . düzeylerde yoğunlaştığı görülmektedir. Bu basamaklardaki beceri tanımlarının daha çok Bloom taksonomisinde ilk iki basamakta yer alan temel düşünme beceri tanımları olduğu görülmektedir. Dolayısıyla Türkiye'deki öğrenci profilinin yıllara göre 
tutarlı bir şekilde temel düşünme becerileri düzeyinde başarı gösterdiğini belirtmek mümkündür. Buna karşın tabloda üst düzey basamaklarda gösterilen beceri tanımları ise analitik düşünme ile doğrudan ilişkili görülmektedir. Bu nedenle dünya standartlarında üst düzey düşünebilme becerisi için öncelikle analitik düşünme becerilerinin geliştirilmesi gerektiği görülmektedir.

Analitik düşünme becerilerinin farklı araştırmacılar tarafından tanımlaması yapılmıştır ancak eğitimde yaygın olarak kullanılan sınıflama Bloom taksonomisidir. Yenilenmiş Bloom taksonomisinin (Anderson ve Krathwol 2001) analiz etme basamağının alt boyutları ayırt etme (differentiating), organize etme, (organizing) ve ilişkilendirme / dayandırma (attributing) olarak belirtilmektedir. Ayırt etme, öğrencinin ilgili olan bilgi ile ilgisiz olanı, önemli olan bilgiden önemsiz olanı ayırt edebilmesi ve ardından ilgili ve önemli olanı kullanabilme becerisidir. Organize etme, bilgilerin parçaları arasında sistematik ve tutarlı bağlantılar kurma becerisidir. Organizasyon genellikle ayırt etme ile birlikte yapılır. Öğrenci önce ilgili veya önemli unsurları tanımlar ve daha sonra bunların yer aldığı genel yapıyı belirler. iliş̧kilendirme / dayandırma ise iletişimin altında yatan bakış açısını, önyargıları, değerleri veya niyeti tespit edebilme becerisidir. Yani öğrencinin metindeki üsluptan yola çıkarak metnin hangi bakış açısıyla yazıldığını ya da yazarın bunu yazmadaki niyetini ortaya koyması gibi becerileri içerir. Bloom taksonomisinin bilişsel bir hiyerarşi oluşturduğu ve bu hiyerarşide alt basamaktaki bilişsel becerileri gerçekleştirmeden üsttekileri gerçekleştirmenin mümkün olmadığı ifade edilmektedir (Karadağ ve Tekercioğlu, 2019). Dolayısıyla analitik düşünme kendi başına bir üst düzey düşünme becerisi olmasının yanında, bu becerilerinin geliştirilmesiyle sentez/yaratma ve değerlendirme basamaklarında gerçekleştirilecek problem çözme, yaratıclık, eleştirel düşünme gibi birçok üst düzey düşünme becerisi için de temel dayanak sağlanabilecektir.

Bu bakış açısıyla hazırlanan bu çalışmanın temel problem cümlesi "Türkçe eğitiminde analitik düşünme becerisinin yeri ve temel dil becerisi alanları ile ilişkisi nedir?" şeklinde belirlenmiştir.

Araştırmanın alt problemleri ise

1. Okuma becerisi ile analitik düşünme becerisi nasıl ilişkilendirilebilir?

2. Dinleme becerisi ile analitik düşünme becerisi nasıl ilişkilendirilebilir?

3. Yazma becerisi ile analitik düşünme becerisi nasıl ilişkilendirilebilir?

4. Konuşma becerisi ile analitik düşünme becerisi nasıl ilişkilendirilebilir?, şeklindedir.

\section{Araştırmanın Modeli}

\section{Yöntem}

Bu çalışma, analitik düşünme becerilerinin içeriğinin ortaokul Türkçe dersi kapsamında nasıl geliştirilebileceği üzerinde durmaktadır. Derleme çalışması şeklinde hazırlanan bu araştırmada, temel nitel araştırma deseni kullanılmıştır. Temel nitel araştırma yöntemi; fenomenoloji, örnek olay ya da örtük teori gibi yöntemlere girmeden yapılan temel ve yorumlayıcı bir çalışma türü olarak tanımlanmaktadır. (Merriam, 2013: 22). Bu çalışmada alanyazın taraması ile elde edilen veriler temel düzeyde yorumlanmış ve analitik düşünme ile nasıl ilişkilendirilebileceği ortaya koyulmuştur. Bu çerçevede ilgili çalışmalardan elde edilen tanımlamalar ile analitik düşünme becerileri ilişkilendirilmiş, daha sonra örnek olarak hazırlanan etkinlik ya da soru tarzı üzerinden analitik düşünme ve temel dil becerilerinin nasıl ilişkilendirileceği açıklanmaya çalışımıştır. Böylece analitik düşünme becerisi ve Türkçe öğretiminin temel dil becerileri öğretimi ilişkisine yönelik yenilenmiş Bloom taksonomisi açısından bir çerçeve ortaya koyulmuştur.

\section{İşlem / Verilerin Toplanması}

Temel nitel araştırmalarda veriler görüşme, gözlem ya da doküman analizi yöntemi ile toplanmaktadır. Çalışma çerçevesinde hangi soruların sorulduğu, neyin gözlendiği ve hangi dokümanların incelendiği çalışmanın teorik çerçevesine bağlanmaktadır (Merriam, 2013). Bu çalışmada veri toplama aracı olarak doküman analizi tekniği kullanılmıştır. Doküman analizi, olgu ve olaylara ilişkin çeşitli kaynaklardan farklı bakış açıları ve yaklaşımların incelenerek sentezlenmesini içermektedir (Baş ve Akturan, 2013). Yapılan alanyazın taraması ile üç temel alanda verilere ulaşılmıştır. Bunlar;

- analitik düşünmeye yönelik çerçeve çizmeyi amaçlayan akademik çalışmalar, 
- temel dil becerileri ile analitik düşünmeyi ilişkilendirmeyi amaçlayan çalışmalar ve

- etkinlik içeriği olarak kullanılabilecek dört temel dil becerisine yönelik yazılı, görsel ve işitsel materyallerden oluşmaktadır.

Yapılan bu çalışma, bahsedilen üç tip verinin ilişkilendirilmesi ve analitik düşünme perspektifinden yorumlanmasını içermektedir.

\section{Verilerin Analizi}

Verilerin analizi için içerik analizi yöntemi kullanılmıştır. İçerik analizi, toplanan verileri açıklayabilecek kavramlara ve ilişkilere ulaşabilmeyi amaçlamaktadır. Bu çerçevede içerik analizinde birbirine benzeyen verileri belirli kavramlar ve temalar çerçevesinde bir araya getirerek okuyucunun anlayabileceği biçimde düzenlenerek yorumlanmaktadır (Yıldırım ve Şimşek, 2011). Buna göre ilk olarak alanyazında temel dil becerilerine ilişkin yapılan tanımlamalar ele alınıp analitik düşünme becerileri açısından yorumlanmıştır. Analiz birimi olarak yenilenmiş Bloom taksonomisinin (Anderson ve Krathwol 2001) analiz basamağının alt boyutlarına göre temel dil becerileri ile analitik düşünme becerileri ilişkilendirilmiştir. Bu alt boyutlar ayırt etme (differentiating), organize etme, (organising) ve ilişkilendirme / dayandırma (attributing) olarak ele alınmıştır. Ardından bu üç başığa yönelik etkinlik ve soru tasarlanıp bunların üzerinde yorumlar yapılmıştır.

\section{Okuma Eğitiminde Analitik Düşünme}

\section{Bulgular}

Okuma becerilerine ilişkin yapılan çalışmalara bakıldığında (Arıcı, 2008; Balcı, 2013; Güneş, 2015; Karatay, 2011b; Özbay, 2009; Özdemir, 2007; Temizkan, 2009) okuma becerisi basılı ya da yazılı sözcükleri duyu organları ile algılayıp bunları anlamlandırma süreci şeklinde ifade edilmektedir. Bu araştırmacılar okumanın unsurlarını ve gerçekleşme sürecini fiziksel ve zihinsel olmak üzere iki temel başlığa ayırmaktadırlar. Tanımdan da anlaşılabileceği gibi okumada temel amaç aslında ifade edilmek istenen anlamın yakalanabilmesidir. Bu noktada düşünme becerileri devreye girmektedir çünkü algılanan iletinin anlamının ortaya koyulması gerekmektedir. Ancak okuma süreci için anlama ve kavramanın yeterli olmadığı aynı zamanda yazılı ve yazısız kaynaklar, okuyucu ve çevrenin ilişkisi gibi birtakım unsurların da etkili olduğu görülmektedir (Karatay, 2011b). Bunu Akyol (2012) şu şekilde açıklamaktadır: Bir metnin başığı "düğün" ise okuyucu metinde geçmese bile düğüü ile ilgili değişik durumları, kendi yaşantılarını hatırlayacak ve anlamı bu şekilde kuracaktır. Görüldüğü üzere okuduğunu anlama süreci, zihinsel olarak birçok işlem gerektiren karmaşık bir süreçtir. Dolayısıyla bir metin bütüncül olarak bir anlamı ifade etme amacı taşıdığı için bütünün parçalarının anlam sürecinde tasnifi ve birbiri arasındaki ilişkilerinin kavranması anlam kurma süreci ile ilgisi yani analitik düşünme becerisi ile ilişkisi son derece önemlidir. Bunun yanında taksonomide analiz basamağında ifade edilen analitik düşünme becerisi aynı zamanda üst düzey olan sentez ve değerlendirme basamakları için öncül bir unsurdur.

Kelime, cümle ve paragraf düzeyinde parçaların meydana getirdiği metinlerin temel amacı bütüncül bir anlamı vermektedir. Metni oluşturan yazar sentetik bir işlem sırası takip ederek parçaları bir araya getirme, yeni bir ürün ortaya koymayı gerçekleştirirken okuyucu analitik bir süreci takip etmektedir. Yani bütünden parçaya doğru inerek metnin parçalarının birbiriyle ve metnin bütünüyle ilişkisinden yola çıkarak bütüncül olarak verilen anlama ulaşır. Parçaları bir araya getirerek bütün oluşturmayı amaçlayan sentetik (bütüncül) düşünmenin zıttı bir şekilde çalışmaktadır. Amer (2005) sentetik ve analitik düşünmenin farkını şu şekilde belirtmektedir: 


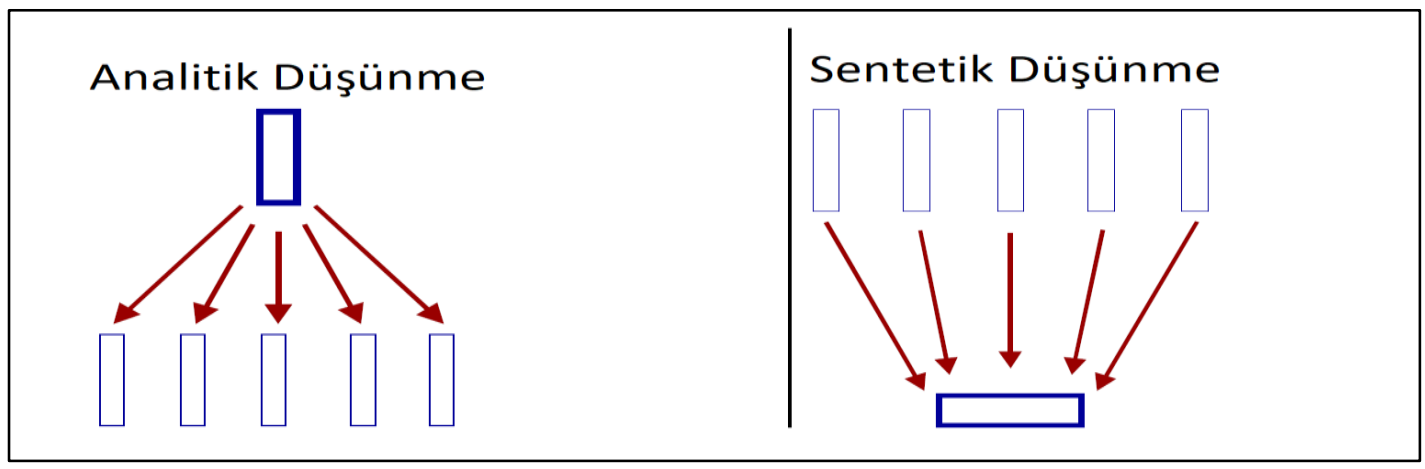

Şekil 1. Analitik ve Sentetik (Bütüncül) Düşünme (Amer, 2005: 4)

Analitik düşünme bütünün parçalara ayrılması temelinde yer aldığı için okuma becerisi çerçevesinde geliştirilmesi son derece etkili bir yöntem olmaktadır. Ancak bu düşünme becerisi, alt başlıkları olan ayırt etme, organize etme ve ilişkilendirme boyutlarında nasıl verilmedir sorusu ele alındığında şu şekilde örnek bir okuma metni ve bu metin ile ilgili etkinlik örnekleri üzerinden açıklamak mümkündür:

Örnek Metin

UZAY YARIŞI

Uzaydaki cisimlerin gözlemi, yani astronomi, bilinen en eski bilimsel çalışmalardan biridir ve güvenilir kayıtlı tarihten öncesine uzanır. 20. yüzyılın başında geliştirilen roketler, uzay keşfinin genişlemesi ve gerçekleşmesine izin vermiştir. Uzayın keşfi, zamanla politik yarışa dönüşür, ülkeleri daha önce keşfetmek için hızlandırır, ABD ve SSCB arasındaki 'uzay yarışı' gibi. Uzay keşfi, tek uçuşlardan, daha çok keşfe imkân veren tekrar kullanılabilir malzemelere kaydı. Uzay keşfinde özel alaka, daha fazla rekabet ve daha büyük devlet görevlerine neden oldu.

İlk uydu fırlatılması 1957'de gerçekleştirildi. Sputnik adında insansız bir hava aracı yaklaşık 150 mil dünyanın yörüngesinde kaldı. Sovyet başarısının ardından, ABD iki ay sonra Vanguard 1 adlı başarısız fırlatışı yaptı. 1958'de ABD Explorer 1'i başarılı bir şekilde fırlattı. 1961'de Vostok 1 adılı araçla ilk insanlı uzay uçuşu gerçekleştirildi, 27 yaşındaki bir adamı taşıyarak. Uzay uçuşu, dünya yörüngesindeki turunu iki saatte tamamladı. Bu zafer, dünyayı uzay keşfinde cesaretlendirdi. $A B D$, Sovyetler'in ardından altı ay içinde onları takip etti. Mercury uçuşu, 20 şubat 1962'de dünyanın çevresinde tam altı tur attı. 1963'te Vostok 6 ile bir kadın dünyanın çevresinde 48 tur attı.

Uzaya bu süreçte canlılar da gönderildi SSCB,1946'da gönderilen meyve sineklerinden sonra, Sputnik2 uçuşu ile yörüngeye gönderilen ilk canlı olan Laike adlı başıboş gezen "fox terrier" cinsi köpeği 1957 yılında uzaya gönderdi. Yıllar sonra yapılan açıklamada köpeğin kalkıştan sonra kalp hızının 3 katı arttığı ve ısı kalkanının da zarar görmesi nedeniyle uçuşun 5.saatinden itibaren hiçbir hayat faaliyeti göstermediği söylenmiştir. SSCB 1960 yılında ilk başarılı canlı uzay yolculuğu gerçekleştirdi. Belka ve Strelka isimli köpekler, Dünya yörüngesine gidip geri dönebildiler. SSCB 1968 yılında, Ay’ın etrafında dolaşan ilk canlılar olan kaplumbağaları gönderdi. Bu sırada uzay yarışında geri kalmak istemeyen Amerika şempanzelerle deneylerini sürdürüyordu.

Şekil 2. Okuma Etkinliğinde Ayırt Etme İçin Metin (metin oluştumak için: https://www.makaleler.com/uzay-kesfi ve https://vukuatlar.com/uzay/uzay-yarisi-1957-1975/ sitelerinden faydalanılmıştır.) 


\section{Okuma Becerisi ve Ayırt Etme}

\begin{tabular}{|l|l|l|l|}
\hline Uçuş Yılı ve Adı & Gönderen Ülke & $\begin{array}{l}\text { Uçuşun Başarı } \\
\text { Durumu }\end{array}$ & Gönderilen Canlı ve Durumu \\
\hline & & & \\
\hline & & & \\
\hline & & & \\
\hline & & & \\
\hline & & & \\
\hline & & & \\
\hline
\end{tabular}

Şekil 3. Okuma Etkinliğinde Ayırt Etme İçin Kullanılacak Tablo

Hazırlanan bu etkinliğin analitik düşünmenin ayırt etme becerisine yöneliktir. Bunun temel nedeni metnin alt yapısında bulunan ögelerin ayrılmasında kategorilerin baştan verilmesidir. Burada öğrenci, hazır olarak verilen kategorilere uygun olan metin ögelerini yerleştirecektir.

\section{Okuma Becerisi ve Organize Etme}

"Okuduğunuz metindeki uzay uçuşlarını tasnif ediniz."

Bu soru için öğrencinin metin içinde yapılandırılmış olan analiz kriterlerini belirmesi gerekmektedir. Yani organize etme becerisinde okur parçaları kendi mantığına göre bir sınıflamaya tabi tutabileceği gibi yazarın metni yapılandırma biçiminin okuyucu tarafından anlaşılması da organize etme becerisine yöneliktir. Bu etkinlikte öğrenci, uçuşları ülkelere göre, başarılı olup olmamasına göre, yıllara göre ya da insan ve diğer canlıların uçmasına göre ayırt edebilir. Organize etme becerisi için öğrencinin hem kriterlerini belirlemesi hem de bu kriterlere göre ayrım yapması gerekmektedir.

\section{Okuma Becerisi ve ilişkilendirme / Dayandırma}

ilişkilendirme / dayandırma becerisi metnin verdiği iletinin ardındaki mesajı anlayabilmeyi ifade etmektedir. Ilişsilendirme sürecinde arka plandaki mesajı anlayabilmek için metin içindeki parçaların birbiri arasındaki ilişkiden ya da parçaların metnin bütünü arasındaki ilişkiden yola çıkarak bir anlamlandırma yapması gerekmektedir. Burada kurulan anlam metnin içinde ifadelerden yola çıkarak örtük mesajın ortaya çıkarılması, metinde anlatılan olayın / durumun nedenini açıklama ya da yazarın metin içinde bir ifadeyi kullanmasında, bir örneği vermesindeki amacı ortaya koyabilmeyi içermektedir. Aşağıdaki soru örnekleriyle bunu şöyle açıklamak mümkündür:

- «SSCB 1960 yılında ilk başarılı canlı uzay yolculuğu gerçekleştirdi. Belka ve Strelka isimli köpekler, Dünya yörüngesine gidip geri dönebildiler.»

Okuduğunuz metinde yer alan bu ifadelerden yola çıkarak, uzaya 1946'da giden meyve sinekleri ve 1957 'de giden Laika için ne söylenebilir? Nedenlerini açıklayınız.

$\mathrm{Bu}$ metinde 1. soruda bahsedilen ifadeye gelene kadarki kısımda canlıların gönderildiğini belirtilmesine rağmen bu canlıların sağ olarak dönüp dönemediğine ilişkin bilgi verilmemiştir. Öğrenciden buradaki ilk başarılı canlı uzay yolculuğu ifadesini yakalaması ve bu ifadeden 1960 yılından önceki canlıların hayatlarını kaybettiğini bulması beklenmektedir. Bunun yapmak için öğrencinin metin içindeki bir dayanaktan önceki ögeler ile belirtilen ögenin farklıı̆̆ını ayırt etmesi gerekmektedir.

- "1961'de Vostok 1 adlı araçla ilk insanlı uzay uçuşu gerçekleştirildi. 1963'te Vostok 6 adlı uzay aracı ile ilk kez bir kadın uzaya uçtu ve dünyanın çevresinde 48 tur attı.»

Yukarıdaki bilgiden hareketle 1961'deki uzay uçuşunu gerçekleştiren kişi ile ilgili hangi bilgi çıkarılabilir? Cevabınızı desteklemek için metinden hareketle bir dayanak gösteriniz.

Bu soru için öğrenci verilen bu iki cümlenin ilişkisinin cinsiyet üzerinden yapılandırıldığını ve anlaması gerekmektedir. Öğrenciden buradaki ikinci cümlede ilk kez bir kadın uzaya uçtu ifadesini yakalaması ve bu ifadeden yola çıkarak ilk uçuşu yapan kişinin bir erkek olduğu çıkarımını yapabilmesi gerekmektedir.

- SSCB 1960 yılında ilk başarılı canlı uzay yolculuğu gerçekleştirdi. Belka ve Strelka isimli köpekler, Dünya yörüngesine gidip geri dönebildiler. 1961'de Vostok 1 adlı araçla ilk insanlı 
uzay uçuşu gerçekleştirildi, bu araç 27 yaşındaki bir astronotu taşıyarak uzay uçuşunu iki saatte tamamladı.

Yukarıdaki bilgilere göre SSCB'nin ilk kez insanlı uçuşunu 1961'de gerçekleştirmesinin nedeni ne olabilir?

$\mathrm{Bu}$ soruda verilen metin parçasında öğrencinin metin içerisindeki ifadelerden ve gerçekleştirilen uçuşların özelliklerinden yola çıkarak SSCB'nin 1961 yılındaki uçuşundaki niyeti anlamlandırması beklenmektedir. 1960 yılına kadar yapılan uçuşlarda canlılar hayatta kalamazken Belka ve Strelka gidip canlı olarak dönebildikleri, yani bir canlının hayatta kalabileceğine emin oldukları uçuştan sonra insanlı bir uçuş gerçekleştirildiğini ifade etmesi beklenmektedir.

- Uzaydaki cisimlerin gözlemi, bilinen en eski bilimsel çalışmalardan biridir ve güvenilir kayıtı tarihten öncesine uzanır.

Yukarıdaki cümlede yazarın italik yazılmış yeri yazmasının nedeni ne olabilir? Açıklayınız

Bu soruda ise öğrenciden metin içindeki birtakım ögelerden yola çıkarak yazarın niyetini anlamlandırması beklenmektedir. Buna göre yazar güvenilir kayıtı tarihle yazının icadından sonraki kayıt altına alınan tarihi ima ederken bunun öncesi M.Ö. 3200 den daha eski bir tarihe dayanmaktadır.

\section{Dinleme Becerisi ve Analitik Düşünme}

Taşer (2009)'in, Konuşma Eğitimi çalışmasının giriş bölümünde "Konuşmanın sentez, dinlemenin ise analiz oluşu" şeklinde bir ifade yer almaktadır. Bu noktada ses ile ifade edilen sözlü metnin anlamlandırıması ve bu anlamlandırma sürecinde metin bütününün parça bütün ilişkisi çerçevesinde yorumlanabilmesini ifade etmektedir. Nitekim dinlemenin kavrama sürecinde algılanan mesajların çözümlenmesi ve değerlendirilmesi işlemi olduğundan bahsedilmektedir (Özbay, 2010; Ünalan, 2006; Yalçın, 2006; ). Burada dinlemenin iletişim boyutunun yanında düşünme becerileri ile ilişkisi de öne çıkarılmaktadır. Nitekim Güneş (2007) dinlemenin öğrenme, anlama ve zihinsel becerileri geliştirme adına önemli bir alan olduğunu ifade etmektedir. Dinleme becerisinin günümüzde medya ve internet seçeneklerinin artmasıyla izleme boyutunun daha ön plana çıktığı da görülmektedir. Bu noktada izlenen medya unsurlarını anlamlandırma ve buralarda işlenen verilerin birbiri ile ilişkisinden yola çıkarak açık veya örtük anlamları da ortaya çıkarma becerisinin analitik düşünme becerileri ile ilişkilendirilebileceği ifade edilebilir.

\section{Dinleme Becerisi ve Ayırt Etme}

Bir Haftada Anadiliniz Gibi İngilizce Konuşun
Ezbersiz, gramersiz, alıştırmasız İngilizce öğretiyoruz!
EasyLearning isimli yeni yöntemle sadece bir haftada anadiliniz gibi İngilizce konuşabilirsiniz.
Yöntemimizde ilk olarak size İngilizce kasetler dinletiyoruz. Böylece dinleme beceriniz gelişirken
farkında olmadan konuşma becerinizin geliştiğini göreceksiniz. Ardından size okutacağımız
metinlerle okuma becerinizi geliştirirken eşzamanlı olarak yazma beceriniz de gelişecek. Yani
konuşma ve yazma beceriniz siz farkında olmadan gelişecek. Hem de hiçbir ilave alıştırmaya gerek
duymadan!
Bir haftada anadiliniz gibi İngilizce konuşmak için tek yapmanız gereken, kursumuza kaydolmak ve
yeni yöntemimizi uygulamanız için alanında uzman hocalarımıza güvenmek.
Türkiye genelinde 12 kişi üzerinde yapılan bir araştırmaya göre \%82 başarı sağlayan bu yöntemle
başarısız olma intimaliniz yok.
Ayrıca bu çalışmada dinleme etkinlikleri sayesinde kursa katılanların müzik kulaklarının da geliştiği ve
katılımcırın daha iyi şarkı söyleyebildikleri de görülmüştür. Bir haftada hem İngilizce öğrenin hem
daha iyi şarkı söyleyin. Bir taşla iki kuş vurmak iç̧in hemen kursumuza kaydolun.
Güvenilir İngilizce Kursları

Şekil 4. Dinleme Etkinliğinde Ayırt Etme İçin Kullanılacak Reklam Metni 
Verilen ilan metni çerçevesinde EasyLearning yöntemiyle aşağıdaki beceri alanlarının nasıl gelişeceklerini ve hangi beceri alanıyla ilişkili olduklarını yazınız.

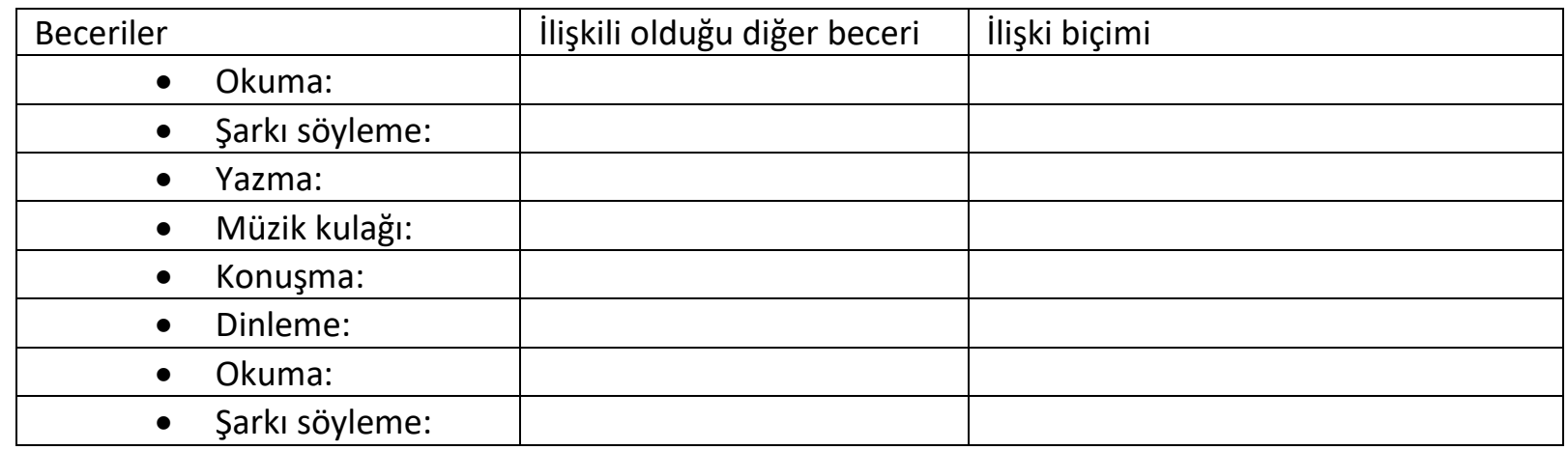

Şekil 5. Dinleme Etkinliğinde Ayırt Etme İçin Kullanılacak Tablo

Hazırlanan bu etkinliğin analitik düşünmenin ayırt etme becerisine yöneliktir. Bunun temel nedeni metnin alt yapısında bulunan elementlerin ayrılmasında kategorilerin baştan verilmesidir. Öğrenci burada hazırlanan kategorilere uygun olan öğe ve bunların arasındaki ilişki biçimini yerleştirmesi gerekmektedir.

\section{Dinleme Becerisi ve Organize Etme}

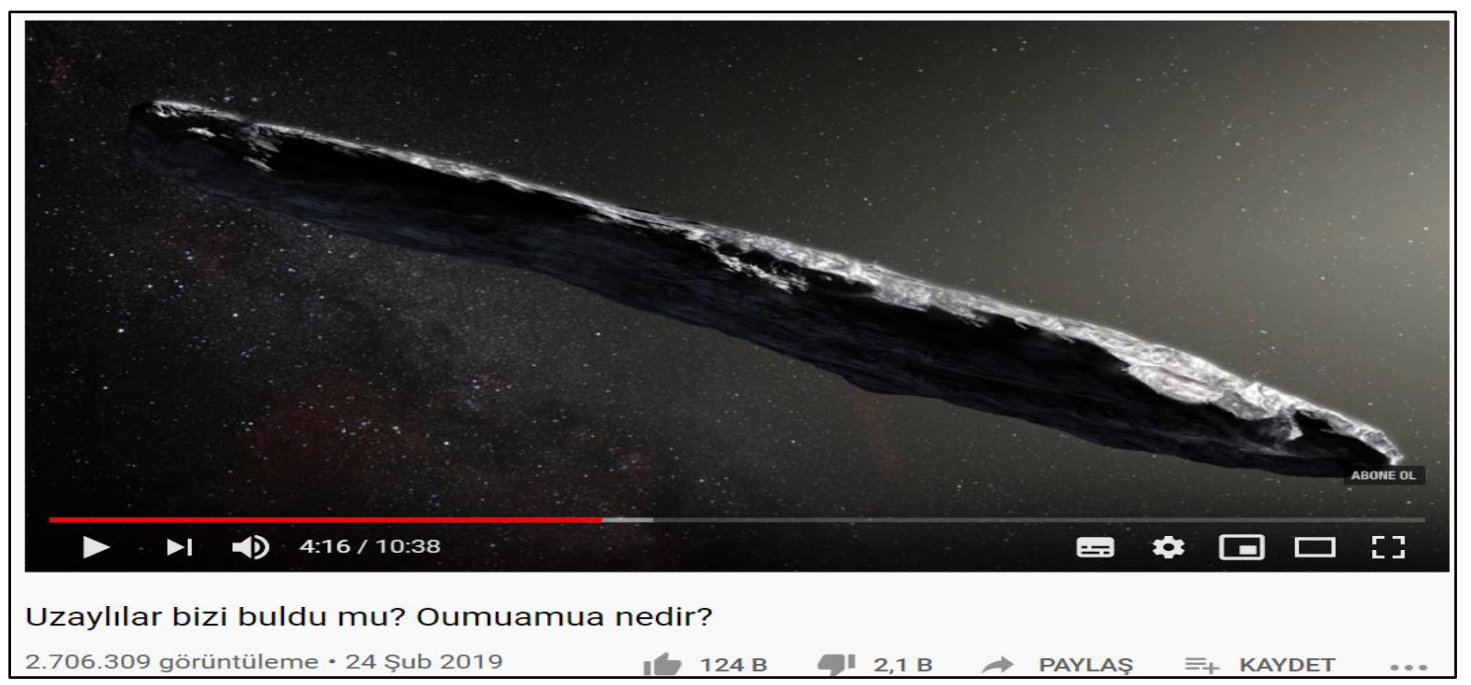

Şekil 6. Dinleme Etkinliğinde Organize Etme ve Iliş̧kilendirme / Dayandırma İçin Kullanılacak Video Ekran Görüntüsü (Kaynak: https://www.youtube.com/watch?v=KWOyOEw2UqY)

- İzlediğiniz videoda örnek olarak verilen kitap, nesne, film vb. örnekleri metnin temel nesnesi olan Oumuama ile ilişkisini belirleyiniz.

Bu etkinlikte öğrencinin metinde belli konuları açıklamak, somutlamak ya da örneklendirmek için verilen kitap, nesne, film vb. örnekleri tespit etmesi ve metinde anlatılan uzay cismi ile ilişkisinin belirlenmesi istenir. Örn:

- Sahildeki taşlar arasındaki farklı taş > Oumuamua da uzay cisimlerinden farklı bir cisim

- Tarih öncesi insanın bulduğu cep telefonunun açıklayamaması > Oumuamua bir uzay gemisi ise günümüz insanının bunun nasıl bir uzay gemisi olduğunu açıklayamaması

Bu tarz bir etkinlikte öğrenciden metnin yapısında bulunan ögeleri tespit etmesi ve ardından bunların arasındaki ilişki biçimini kendi kategorize etmesi gerekmektedir. 


\section{Dinleme Becerisi ve ilişkilendirme / Dayandırma}

- Konuşmacı konuşmanın başında neden sahildeki taşlardan bahsedip farklı görünen taşın doğal olup olmadığını sorgulama örneği veriyor? Metnin devamı ile ilişkilendirerek cevaplayınız.

Bu soruda öğrencinin metin içindeki dayanaklardan hareketle sahilde farklı görünen bir taşın doğal olup olmadığını sorgulamanın, keşfedilen uzay cisminin doğal olup olmadığını sorgulama ile ilgili bir metafor olduğu ayrımını yapması istenmektedir.

- Konuşmacı Rama ile Buluşma isimli romanı neden örnek olarak vermektedir? Metin içinden kanıtlar sunarak açıklayınız.

Bu soruda öğrencilerin, verilen romandaki senaryo ile konuşmacının anlattığı uzay cisminin hareketi, özellikleri, geldiği yer ve bulunuş hikâyesi bakımından benzediğini fark etmesi gerekir. Buradan yola çıkarak öğrencilerin, konuşmacının amacının bu ilginç benzerlikleri vurgulamak ve bazı kaynaklarda cisme neden Rama adının verildiğini açıklamak olduğunu belirtmesi beklenir.

- Videodaki konuşmacının bir kalemin önüne bir kâğıt koyup hareket ettirmedeki amacı nedir?

Öğrencilerin insanlar tarafından yapılan ve metin içinde bahsedilen güneş yelkeni teknolojisi ile uzaydaki Oumuamua cisminin hızlanmasının ilişkilendirildiğini fark etmesi gerekmektedir. Buradan yola çıkarak konuşmacının kalem ve kağıtla yaptığı bu hareketin güneş yelkeni teknolojisiyle bu cismin nasıl gidebileceğini somut biçimde anlattığını ifade etmesi beklenmektedir.

- Konuşmacının Oumuamua nesnesini anlattığı videoda Voyager 1 ve Voyager 2'den bahsetmesinin nedeni nedir?

Konuşmacı Oumuamua cisminin Dünya dışı akıllı bir medeniyetin keşif için gönderdiği cisimlerden biri olma ihtimali üzerinde durmaktadır. Dünya'dan uzayı keşfetmek için de Voyager 1 ve Voyager 2 uzay araçları gönderilmiştir. Burada konuşmacının tahminini dünyadan uzaya gönderilen uzay aracı örnekleriyle desteklediğini ortaya koyması beklenmektedir.

- Konuşmacının "Yine de sahilde dolaşırken, içinde mesaj olan bir şişe bulma fikri bile insanı heyecanlandırmaya yetiyor." cümlesini kurmadaki amacı nedir?

Bu soruda öğrencinin, konuşmacının cümleyi kurmadaki amacını, cümlenin metnin bütünüyle ilişkisinden çıkarması gerekmektedir. Buna göre sahil-içinde mesaj olan şişe metaforununun uzayfarklı gezegenlerden mesaj barındıran uzay gemisi kavramlarına karşılık geldiğini ifade etmesi beklenmektedir.

\section{Yazma Becerisi ve Analitik Düşünme}

Analitik düşünme, bütünü parçalamak üzerine yoğunlaşan tümdengelimsel bir yapıya sahiptir (Amer, 2005). Buna karşın parçadan bütüne giden bir metin oluşturma sürecinde yazma eylemi daha çok sentetik düşünme ile ilişkilidir. Ancak metin oluşturma açısından bakıldığında ilk aşamada, zihinde var olan düşüncelerin ayrıntılandırılması; ana fikir, yardımcı fikirler, olay örgüsü gibi farklı metin ögelerinin arasında birtakım bağlantıların kurulması gerekmektedir (Flower ve Hayes, 1981; Karatay 2011a; Özdemir, 2014; Tompkins, 2000; Tabak ve Göçer 2013). Dolayısıyla yazmanın hazırlık ve planlama aşamalarındaki bu işlemler analitik düşünme ile ilişkilendirilebilir. Bunun temel nedeni, bu gibi metin unsurlarının tek başlarına verilmek istenen anlamı ifade etmeyip diğer unsurlarla ilişkilendirildiği takdirde anlamsal bütünlüğü ifade edebileceğidir. Yazılı anlatımın ikinci boyutu olan kısım ise fiziksel olarak metnin oluşturulduğu bölümdür. Burada da kompozisyon kavramı ortaya çıkmaktadır. Belirli bir düzen içinde bir araya getirme işlemini ifade eden bu kavram, aslen sentez basamağı kullanılarak üretilen fikirleri ya da olay örgülerini düzenleme ve bir araya getirme işlemini ifade etmektedir. Bu fikirlerin ya da olay örgülerinin önem ya da kronolojik sıraya koyma, birbirleri arasında neden-sonuç-amaç-sonuç şeklinde ilişkilendirilmesi, belirli bir ölçüt çerçevesinde karşılaştırılan ögelerin metinde ifade ediliş düzenlerinin belirlenmesi yine analitik düşünme becerileri ile ilgilidir. Yazma becerisinde analitik düşünmenin alt boyutlarına ilişkin ne şekilde bir öğretim yapılabileceği örnek etkinlikler üzerinden şu şekilde gösterilebilir: 


\section{Yazma Becerisi ve Ayırt Etme}

Yazma becerisinde ayırt etmeye yönelik hazırlanacak etkinlikler, özellikle süreç temelli yazmanın planlama aşamasında kullanılabilir. Öğrenci zihninde oluşturduğu fikirleri ya da olay örgüsünü öğretmenin verdiği yazı planı içine yerleştirebilir. Böylece öğretmen tarafından belirlenmiş kategorilere öğrenci tarafından tespit edilen ögeler yerleştirileceği için bu tarz bir etkinlik, ayırt etme becerisine uygun bir etkinlik çeşidi olarak nitelendirilebilir. Böyle bir etkinlik için "Büyük şehirde yaşam ve köyde yaşam karşılaştırın" şeklinde bir yazma görevi verilebilir. Bunun için şehirde ve köyde yaşamanın özelliklerini anlatan ancak bu yönleri olumlu ya da olumsuz olarak betimlemeyen bir metin üzerinden kontrollü yazma etkinliği yapılabilir. Burada, ayırt etme basamağında, öğrenci için kategoriler verilmeli ve öğrenci metin içindeki özellikleri avantaj ya da dezavantaj olarak kendisi betimlemelidir.

Hazırlık: Öğrencilerin kontrollü yazma etkinliği için Büyük Şehirde ve Köyde Yaşam isimli metin verilir. Bu metinde şehir ve köy hayatı için verilenleri iki başlık altında olumlu ve olumsuz olarak ayırmaları istenir. Öğrencilerin verdiği fikirler ve öğretmenin yönlendirmeleri ile her öğrenci şehir ve köy yaşamının özelliklerini ifade eden iki liste çıkarır.

Planlama: Öğrenciler şehir ve köy hayatının özelliklerini olumlu ve olumsuz olarak listeledikten sonra 3 farklı metin şeması verilir ve öğrencilerden bir şema seçmeleri ve listeledikleri özellikleri seçtikleri şemaya uygun olarak metne dönüştürmeleri istenir.

\section{Konu:}

$$
\text { Şema }-1
$$

Ana fikir:

Giriş: Genel tanım

Gelişme -1: Şehirde yaşamanın olumu ve olumsuz özellikleri $(A+, A-)$

Gelişme 2: Köyde yaşamanın olumlu ve olumsuz özellikleri (B+, B-)

Sonuç: Genel fikir.

$$
\text { Şema }-2
$$

Konu:

Ana fikir:

Giriş: Genel tanım

Gelişme -1: Şehirde ve köyde yaşamanın olumlu özellikleri $(A+, B+)$

Gelişme 2: Şehirde ve köyde yaşamanın olumsuz özellikleri (A-, B-)

Sonuç: Genel fikir.

$$
\text { Şema }-3
$$

Konu:

Ana fikir:

Giriş: Genel tanım

Gelişme -1: Şehirde yaşamanın olumlu özelliklerine karşın köyde yaşamanın olumsuz özellikleri (A+, B-)

Gelişme 2: Köyde yaşamanın olumlu özelliklerine karşın şehirde yaşamanın olumsuz özellikleri $(\mathrm{B}+, \mathrm{A}-)$

Sonuç: Genel fikir.

Şekil 7. Yazma Etkinliğinde Ayırt Etmeye Becerisine Yönelik Örnek Yazma Şemaları 
Taslak / Düzenleme: Öğrencilerin belirleyecekleri ana fikre göre listedeki özellikleri metne yerleştirmeleri istenir. Burada, metnin altyapısında bulunan özellikleri öğretmenin hazırladığı şema içine yerleştirdiği için ayrıt etme basamağı da yer alır.

Düzeltme ve Paylaşma: Öğrencilerin hazırladığı metinler son kez kontrol edilir ve düzeltme aşamasından sonra üç faklı şemaya verilen en iyi örnekler sınıf panosunda paylaşılır.

\section{Yazma Becerisi ve Organize Etme}

Yazma becerisinde organize etmeye yönelik uygulamalar yine hazırlık ve planlama aşamalarında yapılacak birtakım etkinliklerle ilişkilendirilebilir. Örneğin, internet kaynaklarının kullanımı isimli bir konu başlığı verilip buna ilişkin öğrencilerden ana fikir ve yardımcı fikirler oluşturmaları söylenip daha sonra bunların birbiriyle bağlantılandırmaları istenebilir. Bu tarz bir etkinlikte, öğrencilerden organize etmeye ilişkin aşağıdaki gibi bir şema çıkarılması beklenebilir. Burada öğrenci, öncelikle ana fikri ardından bunu detaylandıracak yardımcı fikirleri belirlemelidir. Daha sonra bu yardımcı fikirleri de kendi belirlediği kategoriler altında sınıflaması gerekmektedir. Etkinlik sürecinde öğrencinin iki temel işi yapması gerekmektedir. İlki, ana fikrin altında belirlenecek yardımcı fikirleri olumlu ve olumsuz temel kategorilere ayırmak (örneğin bir durum ya da olgu için; olumlu / olumsuz yönleri, bir olay için; nedenleri / oluşumu / geleceğe etkileri, bir sorun için; nedeni / içeriği /çözüm yolları...vb. ) ve fikirlerini belirlediği kategoriler altına yerleştirmektir.

\section{Yazma Konusu: Internet kaynaklarının kullanımı}

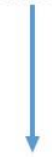

Ana fikir: Internet kaynaklarının kullanımının bilgi edinme sürecimize olumlu ve olumsuz etkileri vardır.

İnternet kaynaklarının bilgi edinme sürecimize olumlu

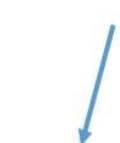

Internet kaynakları bilgi edinmede zaman açısından esneklik sağlamaktadır. etkileri vardır.



İnternet kaynakları fiziksel bir yer kaplamadığı için kullanımı ve iletilmesi pratiktir.

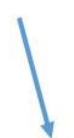

Teknolojinin sunduğu imkanlarla çok fazla sayıda ve çeşitte kaynağa ulaşmak mümkündür.

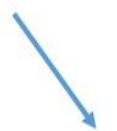

İnternet kaynaklarının bilgi edinme sürecimize olumsuz

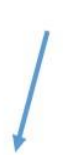

Internet

kaynaklarının kullanımı intihal yapma olasılı̆̆ını arttırmaktadır.

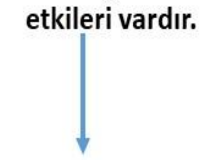

Internetteki bilgi kaynaklarının güvenilirliği konusunda sorun yaşanabilmektedir.

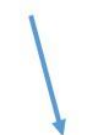

Internet kaynaklarının sunduğu çok miktarda ve çeşitte bilgiden gerekli olanı ayırt etme zorunluluğu vardır.

Şekil 8. Yazmada Organize Etmeye Yönelik Öğrenciden Beklenen Örnek Bir Gruplandırma 


\section{Yazma Becerisi ve ilişkilendirme / Dayandırma}

Tür temelli yazma

Model alma aşaması

\section{BERGAMA KÜTÜPHANESI}

Anadolu'nun en eski ve en zengin kütüphanesi olan Bergama Kütüphanesi, Pergamon Kralı II.Eumenes (M.Ö. 197-159) tarafından yaptırılmıştı. Antik çağın en önemli kütüphanelerinden biri olan Bergama Kütüphanesi, döneminin en önemli kitaplarını içinde barındırıyordu.

Bergama Kütüphanesi'nin, İskenderiye Kütüphanesi'nden sonra kurulmasına rağmen hızla gelişerek 200.000 ruloluk yazma esere ulaşması üzerine, İskenderiye Kütüphanesi'ni geçmesinden endişe eden Mısır Kralı Ptoleme Epiphenes (M.Ö. 205-182) Bergama'ya papirüs ihracını yasaklamıştı.

Yazı yazma malzemeleri kesilen Bergamalılar kısa bir şaşkınlık devresinden sonra aslında daha önceden keçi ve koyun derisinden yapmayı bildikleri parşömeni geliştirerek, derinin üzerine yazı yazmaya başladılar. Önceleri tüysüz kısmı kullanırken daha sonra her iki yüzüne de yazı yazılmaya başlanan parşömen, nemli Akdeniz ikliminde papirüse oranla daha dayanıklı olduğu için, tercih edilmeye başlandı ve M.S. 3-5 yüzyıllar arasında çok yaygın olarak kullanıldı. Parşömenin geniş ölçüde kullanımı; yapraklar halinde kesilip, deri iplerle bağlanarak bugün kullandığımız kitapların ilk örnekleri olan Codexlerin de yolunu açmıştır.

Sürekli rekabet içindeki bu iki önemli kütüphane benzer bir sonla karşılaştılar. İskenderiye Kütüphanesi'nin yazmaları M.Ö. 47 yılında Sezar'ın İskenderiye'yi işgali sırasında yanarak yok oldu. Bu duruma çok üzülen Mısır Kraliçesi Kleopatra'yı etkilemek isteyen Antonius, M.Ö.41 yılında Bergama Kütüphanesi yazmalarını gemilerle Mısır'a taşıtarak kraliçeye hediye etti. Ancak Bergama Kütüphanesi yazmaları da daha sonraki bir savaş ertesinde yanarak tamamen yok oldu. Böylece insanlık tarihinin bu büyük bilgi depoları, ne yazık ki yine insanoğlu tarafından yok edilerek karanlığa gömüldü.

Şekil 9. Yazmada İlişkilendirme / Dayandırmaya Yönelik Etkinlik iç̧in Kullanılabilecek Metin Örneği.

(Metin için http://bergamakutuphane.blogspot.com/2013/ sitesinden faydalanılmıştır.)

Inceleme konusu 1: Yazının amacını ortaya koyma

Öğrencilerden, yazarın bu yazıyı yazmadaki temel amacını metindeki ipuçlarından yola çıkarak açıklamaları beklenir. Alınan cevaplardan sonra öğrencilere, metnin yapısı itibarıyla tanıtıcı bir metin olduğu anlatılır.

Inceleme konusu 2: Metindeki yer alan örneklerin verilme nedenlerini ortaya koyma

Yazarın Bergama Kütüphanesi'ni anlattığı bu yazıda İskenderiye Kütüphanesi'nden bahsetme nedenini bulmaları beklenir. Daha sonra öğrencilere yazıda örneklerle anlatılmak istenen düşüncelerin nasıl ilişkilendirildiği anlatıır.

Inceleme konusu 3: Yazarın fikrî ve duygusal tutumunu metindeki ifadelerden, dil ve üsluptan yola çıkarak belirleme

Öğrencilerden, yazarın metin içinde kullandığı ifadelerden, dil ve üslubundan yola çıkarak duygusal durumunu ortaya koymaları beklenir. Daha sonra yazılı anlatımda fikrî veya duygusal tutumun metin içerisindeki ifade yapısıyla nasıl ifade edilebileceği üzerinde durulur. Örneğin bu metinde yazarın; "Böylece insanlık tarihinin bu büyük bilgi depoları, ne yazık ki yine insanoğlu tarafından yok edilerek karanlığa gömüldü." ifadesiyle tarihi kütüphanelerin yok olmasına üzüntüsünü ortaya koyduğu ifade edilebilir.

Inceleme konusu 4: Belirli ifade kalıplarını / cümleleri kullanmada yazarın amacını ortaya koyma

Öğrencilerden, metin içinde kullanılan belirli ifade kalıplarından ya da cümlelerden yazarın amacına yönelik çıkarımlarda bulunmanın mümkün olduğu belirtilebilir. Örneğin: "Parşömenin geniş 
ölçüde kullanımı; yapraklar halinde kesilip deri iplerle bağlanarak sayfalar halinde, okunması daha kolay olan Codexlerin de yolunu açmıştır." cümlesiyle aslıdan yazarın, günümüzde kullandığımız kitapların ilk ortaya çıkışını Bergamalılara dayandırdığı belirtilebilir. Yine benzer "bir kaderi paylaştı" ibaresinin de yine yazar tarafından Bergama Kütüphanesi'nin sonunun İskenderiye Kütüphanesi'nin sonu ile ilişkilendirildiği ifade edilebilir.

Birlikte yazma aşaması:

Yazı Konusu: Dostluğun önemi hakkında bir yazı yazınız.

Konu: Dostluğun hayatımızdaki yeri

Ana fikir: $\quad$ Öğrencilerle dostluğun insan için vazgeçilmez bir unsur olduğunu ifade eden bir ana

fikir belirlenir.

Yardımcı fikirler: İçeriğe uygun olarak öğrencilerle birlikte yardımcı fikirler oluşturulur. Metni yazarken;

- Yazının amacının dostluğun önemini ortaya koyma olduğu belirtilip bunun metin üzerinde gösterilmesine dikkat edilir.

- Metinde dostluğun önemini anlatmak üzere dostu olan bir insanla dostsuz kalan bir insanı karşılaştıran örnek durum verilir. (örneklerle fikirleri eşleştirme)

- Dostluğun önemini savunduğumuzu belirten ifadeler kullanılır: önemlidir, gereklidir, aksi halde....olurdu, dostluğun...olduğu unutulmamalıdır...vb. (dil ve üslubu, kelime seçimini yazıdaki fikrî durumu ortaya koyacak şekilde düzenleme)

- Belirli amaçlarla kalıp ifadeler ya da örnek olaylar metne yerleştirilir ve bunun metnin ögeleri ile nasıl ilişkilendirildiği gösterilir. (Örn: "Hatasız dost arayan dostsuz kalır" sözünün ya da "dostlarını en küçük ihmalinde terk eden birinin yalnız kaldı̆ıı" bir hikâyenin "Zor kazanılan dostlukların kıymetini bilmeliyiz" şeklindeki bir yardımcı fikirle ilişkilendirilmesi)

Serbest Yazma Aşaması

Öğrencilere empatinin hayatımızdaki yeri hakkında bir yazı ödevi verilip birlikte yazma aşamasında yapıldı̆̆ı gibi;

- yazının amacını metindeki ögelerle ortaya koymaları

- metindeki yer alan örneklerin verilme nedenlerini ortaya koymaları

- savundukları fikri metindeki okuyucuya sezdiren ifadeler, dil ve üslup kullanmaları

- amaçlarına uygun belirli ifade kalıplarını / cümleleri kullanma konularına dikkat ederek bir yazı yazmaları istenir.

Yansıtma Aşaması

Öğretmen bu aşamada ödev metinlerini okuyup değerlendirir ve öğrencilere dönütler verir.

\section{Konuşma Becerisi ve Analitik Düşünme}

Konuşma becerisi insanın duygu, düşünce, hayal ve bilgilerini ses ve vücut hareketleri ile karşısındaki insana anlatması olarak ifade edilmektedir (Kurudayıoğlu, 2014; Topçuoğlu Ünal ve Özden, 2014). Konuşma becerisi, yazma becerisi gibi dinleme ve okumadan beslenen üretici bir anlatma becerisidir (Baş, 2009). Bu nedenle bu iki beceri anlatım teknikleri olarak daha çok yaratım süreci ile (Taşer, 2009) yani sentetik düşünmeyle ilgilidir. Buna karşın tıpkı yazma becerisinde olduğu gibi konuşma becerisinin ortaya koyulma sürecinde de zihinde oluşan fikirlerin doğru bir şekilde ayrıntılandırılması ve bu ayrıntılar arasındaki ilişkilerin doğru bir şekilde yapılandırılması yine analitik düşünme becerileri ile ilişkilidir. Konuşma becerisine ilişkin Türkçe ders kitaplarındaki etkinliklere bakıldığında genel olarak temada işlenen konuya ilişkin öğrencilere konuşma yaptırılmaktadır. Bu temalarda, konunun anlam ve önemini ifade eden etkinlilerde öğrencinin temadaki konuya ilişkin verilen özellikleri birbiri ile ilişkilendirerek ifade etmesi, benzer bir tecrübesini temadaki durumla ilişkilendirerek aktarması ya da belirli bir probleme ilişkin öğrencinin orijinal çözümünü sözel olarak anlatmasını içeren etkinlikler verilmektedir. Bu etkinliklerde öğrencilerden ders kapsamında öğrendiklerini ya da ürettikleri düşünceleri düzenlemeleri ve bunları örgütleyerek konuşma becerisi ile ifade etmeleri beklenmektedir. Behn ve Vaupel (1976), analitik düşünme becerisi için sınırlı zaman ve bilgiyi kullanarak düşünceleri örgütleme ve karar verme olarak ifade etmektedir. Buna göre konuşma 
etkinliklerinde de gerek derste anlatılanların gerekse öğrencinin yaratıcı düşünmesiyle oluşturduğu fikirlerin bir konuşma metni olarak düzenlenip ifade edilmesi için analitik düşünme becerilerine ihtiyaç duyulmaktadır. Konuşma becerisinin düzenlenmesine ilişkin analitik düşünme becerileri şu şekilde kullanılabilir:

\section{Konuşma Becerisi ve Ayırt Etme}

Konuşma becerisinde ayırt etme ile ilgili bir etkinlik için öncelikle yapılan bir okuma ya da dinleme/izleme etkinliğinin ardından öğrencilerin metinde bahsedilen konuların avantajlar dezavantajlar, yararları - zararları, olayın öncesi - olayın gerçekleşme biçimi - olayın sonucu gibi temel başlıklara ayırabilmesi ve bunları sözlü olarak ifade edebilmesi beklenir. Güdümlü konuşma yönteminin kullanılabileceği bu tarz bir etkinlikte, öncelikle okuma ya da dinleme/izleme etkinliği yapılır. Daha sonra öğrencilerden öğretmen tarafından belirlenen başlık ve kategoriler üzerine konuşma yapmaları istenir. Örnek olarak "GDO'lu ürünlerin insanlık için yararları ve zararları" ya da "Çanakkale Savaşı'nın öncesi, savaş sırasında gerçekleşenler ve sonuçları" gibi konular olabilir. Ardından öğrencilerden buldukları ögeleri öğretmen tarafından belirtilen ilgili kategoriler çerçevesinde konuşma metninde ele almaları beklenir.

\section{Konuşma Becerisi ve Organize Etme}

Konuşma becerisine yönelik bir ayırt etme etkinliğinde, verilen konu başlığı üzerinde öğrenci bir konuşma yaparken öncelikle konu ile ilgili kategorileri kendinin belirlemesi ve yine bu kategorilerde değineceği alt başılıları yerleştirebilmesi gerekmektedir. Örneğin yapılacak bir serbest konuşma etkinliğinde, önce öğretmen tarafından "Geçmiş zaman ile şimdiki hayatınızı karşılaştııın." konusunu verilebilir. Burada öğrencinin geçmiş zaman ile günümüzü karşılaştıracak belirli konu başlıklarını belirlemesi ve daha sonra bunların altında değinebileceği alt başlıkları ifade etmesi beklenir. Örneğin yalnızca A. Geçmiş ve B. Günümüz başlıkları verilmiş olan bir tabloya öğrencilerin şu şekilde bir konuşma planı hazırlaması beklenmektedir.

\begin{tabular}{|c|c|c|c|c|c|}
\hline \multicolumn{3}{|c|}{ A. Geçmiş } & \multicolumn{3}{|c|}{ B. Günümüz } \\
\hline 1. Yaşam Tarzı & 2. İş dünyası & 3. Teknoloji & 1. Yaşam Tarzı & 2. İş dünyası & 3. Teknoloji \\
\hline $\begin{array}{l}\text { * Mahalle } \\
\text { kültürü } \\
\text { *Küçük şehirler } \\
\text {.... }\end{array}$ & $\begin{array}{l}\text { * Küçük } \\
\text { işletmeler } \\
\text { *El gücü ile } \\
\text { yapılan işler } \\
\text {.. }\end{array}$ & $\begin{array}{l}\text { * Daha az } \\
\text { teknoloji } \\
\text { bağımlılığı } \\
\text { * Kablolu } \\
\text { aletler } \\
\ldots\end{array}$ & $\begin{array}{l}\text { * Sitede yaşama } \\
\text { * Büyük } \\
\text { metropoller } \\
\text { * Bireysel yaşam } \\
\text { tarzı } \\
\text {... }\end{array}$ & $\begin{array}{l}\text { * Büyük } \\
\text { fabrikalar } \\
* \text { Otomasyon } \\
\text { ile çalışma ... }\end{array}$ & $\begin{array}{l}\text { * Teknoloji } \\
\text { bağımlılığı } \\
{ }^{*} \text { Kablosuz } \\
\text { teknolojiler } \\
\ldots .\end{array}$ \\
\hline
\end{tabular}

Şekil 10. Konuşma Becerisinde Organize Etmeye Yönelik Öğrenciden Beklenen Örnek Bir Gruplandırma

Şekil 10'da görülebileceği üzere öğretmen geçmiş ve günümüz olmak üzere iki temel başlığı belirlese de öğrenci bunun altında 3'er farklı kategori belirlemiş ve her bir kategori altında alt başıkları sınıflandırmıştır. Ardından öğrenci, oluşturduğu kategorilerden yola çıkarak bir konuşma yapmalı ve bu

Örnek Konuşma Şeması

Giriş: Genel tanım

Gelişme -1: Geçmişteki hayatın çeşitli yönlerle tanıtılması (A1 - A2 - A3)

Gelişme - 2: Günümüzdeki hayatın çeşitli yönlerle tanıtılması ( B1 - B2 - B3)

Sonuç: Konuşmacının savunduğu fikir. 
konuşmada da içeriği nasıl oluşturması gerektiğine yine kendi karar vermelidir. Böylece belirlediği alt başlıklar ve maddeler arasındaki ilişkilendirmeyi de yine öğrenci yapacaktır. Bu tarz bir etkinlik için konuşma şeması şu şekilde yapılandırılabilir:

Şekil 11. Konuşma Becerisinde Organize Etmeye Yönelik Öğrenciden Beklenen Örnek Bir Konuşma Planı

\section{Konuşma Becerisi ve ilişkilendirme / Dayandırma}

Konuşma becerisinde ayırt etme etkinliği için öğrencilere mevcut bir problem durumu verip buradaki ikilem durumlarının nasıl ilerleyebileceğine yönelik hazırlıksız konuşma etkinliği yaptırılabilir. Böylece öğrencinin ilk etapta ikilem durumunu kavraması, daha sonraki etapta ise metin içindeki ögelere dayandırarak hikayenin nasıl devam edeceğini ifade etmesi gerekmektedir. Burada öncelikle ayırt etme etkinliği yaptırılıp ardından ilişkilendirme etkinliğine geçilebilir. Bunu, aşağıdaki gibi bir örnek etkinlik üzerinden anlatmak mümkündür.

\section{Burhan ve Kürşat'ın İkilemleri}

Burhan derslerinde çok başarılı bir öğrencidir. Bir hafta sonu ailesiyle gittiği alışverişte çok güzel bir oyun konsolu görür ve onu almak için para biriktirmeye başlar. Tam oyun konsolu için parayı tamamlamışken konsola zam gelir ve parası yetmez. Bunun için arkadaşı Kürşat'tan borç ister. Arkadaşı ise borç vermek için hafta sonu yapması gereken proje ödevini Burhan'ın yapmasını şart koşar. Burhan eğer hafta sonu Kürşat'ın ödevini yapmazsa oyun konsolunu alamayacaktır ancak yaparsa bu defa da kendi ödevini yetiştiremeyip düşük not alacaktır.

Kürşat'ın 3 yıldır görmediği dayısı Türkiye'ye gelecek ve yalnızca bir hafta sonu için Kürşatların evinde kalacaktır. Ancak Kürşat'ın o hafta sonu proje ödevi vardır ve eğer dayısı ile görüşürse proje ödevini yetiştiremeyecektir. Proje ödevini yaparsa bu defa dayısıyla en az 1 yıl daha görüşmesi mümkün görünmemektedir. Tam bu sırada Burhan'ın borç istemesi aklına ödevini Burhan'a yaptırma fikrini getirmiştir fakat bu konuda vicdani olarak rahatsızlık duymaktadır.

Yukarıdaki ikilem durumlarını göz önüne alarak hem Kürşat hem de Burhan'ın kabul edebileceği bir çözüm durumu tasarlayıp ve bunu sınıfa sözlü olarak anlatınız.

Şekil 12. Konuşma Becerisinde Illişkilendirmeye Etmeye Yönelik Kullanılacak Örnek Metin

Bu tarz bir etkinlikte öğrencilerden ilk olarak metin içindeki ikilem durumlarını tespit etmeleri, daha sonra ise bunlardan yola çıkarak bir çözüm yolu önermeleri beklenmektedir. Burada öğrenciler bireysel ya da grupla bir konuşma etkinliği planlayıp sunum yapabilirler. i̇kna edici konuşma yönteminin kullanılabileceği bu tarz bir etkinlikte öğrencilerin, buldukları çözüm önerilerini metin içerisinde yer alan verilere dayandırmaları gerekmektedir. Daha sonra öğrencilerin, yaptıkları sunumlarla en mantıklı seçimin sundukları çözüm yolu olduğuna dinleyicileri ikna etmeye çalışmaları beklenmektedir. Buradaki örnekte öğrencilerin üç farklı farazi durum üzerinden çözüm önerilerini sunmaları gerekmektedir. Bu senaryolar:

- Burhan'ın teklifi kabul edip Kürşat'ın ödevini yaptığı, kendi ödevini yapmayıp düşük not aldığı ancak oyun konsolunu alıp Kürşat'ın dayısı ile görüştüğü senaryo

- Burhan'ın teklifi reddedip kendi ödevini yaptığı, oyun konsolunu alamadığı ancak Kürşat'ın dayısını görmeyi seçip dersten kaldığı senaryo

- Burhan'ın teklifi reddedip kendi ödevini yaptığı, oyun konsolunu alamadığı ancak Kürşat'ın ödev yapmayı seçip dayısını göremediği senaryo

Öğrencilerin bu senaryolar üzerine düşünüp bağlamdan çıkmadan bir sonucu tercih etmeleri ve bunun sebeplerini yine metin içinden sebeplere dayandırarak konuşmaları gerekir. Böylece 
öğrenciler hem konuşma becerileri geliştirirken hem de olayların birbiri ile neden - sonuç, amaç sonuç gibi ilişkilerini kavrayabilecektir.

\section{Sonuç ve Öneriler}

Yapılan bu çalışmada, analitik düşünme becerisinin temel dil becerilerinin öğretimi ile ilişkisi ve bu çerçevede ne şekilde ele alınması gerektiği üzerinde durulmuştur. Yapılan alanyazın taramasında elde edilen veriler ve PISA sınav sonuçlarına bakıldığında, analitik düşünme becerisinin verilen eğitim ile geliştirilebileceği ortaya koyulmaktadır. Buna göre Türkiye' nin PISA puanlarında genel ortalamasının düşük olmasının yanında üst düzey düşünebilen öğrenci oranının da düşük olması aslında üst düzey düşünme becerisinin geliştirilmesindeki eksikliği ortaya koymaktadır. PISA'nın okuma becerileri taksonomisinin üst basamaklarda yer alan beceri tanımlarının büyük ölçüde analitik düşünme ile örtüştüğü görülmektedir. Bunun yanında analitik düşünme, değerlendirme ve yaratma basamaklarına yönelik bir ön basamak olduğu için üst düzey düşünme becerilerine yönelik de anahtar bir rol üstlenmektedir. Analitik düşünme, bütünü parçalarına ayırma ve parçaların kendi aralarında ve bütünle olan ilişkisini kapsadığı için temel dil becerileri açısından bakıldığında anlama tekniklerine yani okuma ve dinleme becerisine yönelik etkinliklerde daha etkin kullanıldığı görülmektir. Bunun temel nedeni okuma ve dinleme etkinliklerinde metnin anlaşılması, çeşitli değişkenlere yönelik metin unsurlarının incelenmesi gibi uygulamaları içermesidir. Buna karşın konuşma ve yazma becerileri daha çok sentez basamağı ile ilgilidir ve bir bütünü oluşturan yaratım sürecini ifade etmektedir. Ancak hem yazma hem de konuşma becerilerinin oluşturulmasında düşüncelerin veya olay örgüsünün ayrıntılandırılması, sözlü veya yazılı metinlerin düzenlenmesi, metin yapısına bu düşüncelerin ve olayların yerleştirilmesi gibi konularda aslında analitik düşünme becerilerinin işe koşulduğu görülmektedir. Dolayısıyla eğitim sürecinde analitik düşünmenin yerini ve önemini Türkçe eğitimcilerinin doğru kavrayıp öğrencide bu beceriyi geliştirmeye özen göstermeleri gerekmektedir. Bu görüşler ve yapılan çalışma sonucunda şu şekilde öneriler sunulabilir:

- Analitik düşünme becerisi alanyazında problem çözme becerisi ile yoğun bir biçimde ele alınmaktadır. Bu noktada problem çözme becerisi ile ilişkisini ele alan bir çalışma yapılabilir. Bunun için günlük hayatta karşılaşılabilecek problem durumları üzerinden uygulamalar yapılabilir.

- Bu çalışmada analitik düşünme becerisinin temel boyutları ve içeriği ele alınmıştır. Ancak alanyazında daha üst düzey taksonomik becerilere hitap eden yaratıcı düşünme ve eleştirel düşünme ile ilişkisi ortaya koyulmalıdır.

- Okuma becerisi açısından analitik düşünme becerilerinin anlamaya katkısı göz önüne alınarak okuma stratejilerinin uygulanması ile ilişkilendirilmelidir.

- Yazma becerisi açısından özellikle metnin düzenlenmesi için kullanılabilecek analitik düşünme becerileri, metin düzenlenmesi açsından süreç temelli ve tür temelli yapılan bütüncül uygulamalara adapte edilebilir.

- Konuşma becerisi açısından hazırlıklı ve hazırlıksız konuşma süreçlerinde öğrencilerin fikirlerini ya da olay örgüsünü nasıl ayarladığı tespit edilerek karşılaşılan durumlara uygun ideal sözlü metin şemalarının öğretimi sağlanabilir.

- Dinleme becerisi açısından medya metinlerini dinleme / izleme etkinliklerinde uygulanarak özellikle dijital okuryazarlık ve medya okuryazarlığının analitik düşünme ile ilişkisi ele alınabilir.

\section{Kaynaklar}

Akyol, H. (2012) Türkçe ilk okuma yazma öğretimi. 11. Baskı, Ankara: Pegem Akademi.

Amer, A. (2005). Analytical thinking. Pathways to Higher Education.

Arıcı, A. F. (2008). Okuma eğitimi. Pegem Akademi.

Ataman, A. (2012). Üstün yetenekli çocuk kimdir. Geleceğin Mimarları Üstün Yetenekliler Sempozyumu, 27, 4-15.

Balcı, A. (2013). Okuma ve anlama eğitimi. Ankara: Pegem Akademi Yayıncılık. 
Baş, B. (2012). Illköğretim Türkçe programına sözlü ve yazılı kültür temelli bir eleştiri. Kastamonu Eğitim Dergisi, 20(1), 271-290.

Baş, T. ve Akturan, U. (2013). Nitel araştırma yöntemleri. 2. Baskı, Ankara: Seçkin Yayıncılık. Behn, R. D. ve Vaupel, J. W. (1976). Teaching analytical thinking. Policy Analysis, 663-692.

Bloom, B. S., Engelhart, M. D., Furst, E. J., Hill, W. H. ve Krathwohl, D. R. (1956).Taxonomy of educational objectives: Handbook I: Cognitive domain. New York, NY: David McKay.

Brookhart, S. M. (2010). How to assess higher-order thinking skills in your classroom. Alexandria, VA: ASCD.

Çakır, N. (2013). Üniversite eğitiminin üst düzey düşünme becerilerinin gelişimine etkisi. Yayımlanmamış Doktora Tezi. Hacettepe Üniversitesi, Ankara

Çakır, N. ve Senemoğlu, N. (2016). Yükseköğretimde analitik düşünme becerileri. Kastamonu Eğitim Dergisi, 24(3), 1487-1502.

Çerçi, A. (2018). Türkçe Dersi Öğretim Programı kazanımlarının (5, 6, 7, 8. Sınıf) Yenilenen Bloom Taksonomisi'ne göre incelenmesi. Okuma Yazma Eğitimi Araştırmaları, 6(2), 70-81.

Descartes, R. (2014). Aklın yönetimi için kurallar. Çev. Engin Sunar, İstanbul: Say Yayınları.

Durukan, E. ve Demir, E. (2017). 6, 7 ve 8. sınıf Türkçe dersi öğrenci çalışma kitaplarındaki etkinliklerin Bloom'un yenilenmiş taksonomisine göre sınıflandırılması. Uluslararası Türkçe Edebiyat Kültür Eğitim (TEKE) Dergisi, 6(3), 1619-1629.

Eroğlu, S. (2019). 6. sınıf türkçe ders kitaplarındaki metin altı okuma-anlama soru ve etkinliklerinin güncellenmiş Bloom taksonomisine göre değerlendirilmesi. Yayımlanmamış Yüksek Lisans Tezi, Balıkesir Üniversitesi Sosyal Bilimler Enstitüsü, Balıkesir.

Filiz, S. B., \& Yıldıım, N. (2019). Ortaokul Türkçe dersi öğretim programı kazanımlarının revize edilmiş Bloom taksonomisine göre analizi. Elementary Education Online, 18(4).

Flower, L., \& Hayes, J. R. (1981). A cognitive process theory of writing. College composition and communication, 32(4), 365-387.

Güneş, F. (2015). Etkinliklerle hızlı okuma ve anlama. Ankara: Pegem Akademi.

Güneş, F. (2007). Türkçe öğretimi ve zihinsel yapılandırma. Ankara: Nobel Yayın Dağıtım.

Güneş, F. (2012). Öğrencilerin düşünme becerilerini geliştirme. Türklük Bilimi Araştırmaları, 32(32), 127-146.

Kabacaoğlu, T. (2009). Türkiye'de 2 milyon üstün zekâlı çocuk var. http://www.aktuelpsikoloji.com/turkiyede-2-milyon-ustun-zekali-cocuk-var-5593h.htm erişim: 14.05.2020.

Kang, S. (1999). Higher Order Thinking Skills in Language Education. The Korean Language in America, 3, 35-40.

Kapanadze, D. Ü. (2019). 2018 Türkçe Öğretim Programı́ndaki kazanımların üst düzey düşünme becerileri bağlamında incelenmesi. Milli Eğitim Dergisi, 48(223), 83-112.

Karadağ, Ö. ve Tekercioğlu, H. (2019). Türkçe Ders Kitaplarındaki Bilişsel ve Üstbilişsel İşlevlere Dair Bir Durum Tespiti. Mersin University Journal of the Faculty of Education, 15(3).

Karatay, H. (2011a). 4+ 1 planlı yazma ve değerlendirme modelinin öğretmen adaylarının yazılı anlatım tutumlarını ve yazma becerilerini geliştirmeye etkisi. Turkish Studies, 6(3), 1029-1047.

Karatay, H. (2011b). Okuma eğitimi kuram ve uygulama. Ankara: Berikan Yayınevi.

Kurudayıoğlu, M. (2013). Konuşma eğitimi. 2. Baskı, İstanbul: Kriter Yayınları.

Markman, K. D., Lindberg, M. J., Kray, L. J. ve Galinsky, A. D. (2007). Implications of counterfactual structure for creative generation and analytical problem solving. Personality and Social Psychology Bulletin, 33(3), 312-324.

MEB, (2005). PISA 2003 projesi ulusal nihai rapor. Ankara: MEB Basımevi.

MEB, (2010a). PISA 2006 projesi ulusal nihai rapor. Ankara: MEB Basımevi.

MEB, (2010b). PISA 2009 projesi ulusal nihai rapor. Ankara: MEB Basımevi.

MEB, (2015). PISA 2012 araştırması ulusal nihai rapor. Ankara: Ölçme, Değerlendirme ve Sınav Hizmetleri Genel Müdürlüğü.

MEB, (2016). PISA 2015 projesi ulusal nihai rapor. Ankara: MEB Basımevi. 
MEB, (2019) PISA 2018 Türkiye ön raporu. Eğitim Analiz ve Değerlendirme Raporları Serisi No:10. Ankara: Milli Eğitim Bakanlığı.

Merriam, S. B. (2013). Nitel araştırma: Desen ve uygulama için bir rehber. Ankara: Nobel Yayınevi. Ohlsson, S. (2011). Deep learning: How the mind overrides experience. Cambridge University Press. Özbay, (2010). Anlama teknikleri - II: Dinleme eğitimi. 2. Baskı, Ankara: Öncü Kitap

Özbay, M. (2009). Anlama teknikleri - I: Okuma eğitimi. 1. Baskı, Ankara: Öncü Kitap

Özdemir, B. (2014). Analitik yazma ve değerlendirme modelinin Türkçe öğretmeni adaylarının yazma becerilerine ve yazma tutumlarına etkisi. Yayımlanmamış Doktora Tezi. Gazi Üniversitesi Eğitim Bilimleri Enstitüsü. Ankara.

Özdemir, E. (2007). Eleştirel okuma. Ankara: Bilgi Yayınevi.

Özdemir, O. (2019). Türkçe öğretme ve öğrenmenin anlamı. K. Bulut ve M.N. Kardaş (Ed.) Türkçe öğrenme ve öğretim yaklaşımları (ss. 59-86). Ankara: Pegem Akademi

Robbins, J. K. (2011). Problem solving, reasoning, and analytical thinking in a classroom environment. The Behavior Analyst Today, 12(1), 41

Sezgin, Z. Ç. ve Özilhan, Y. G. G. (2019). 1.-8. sınıf Türkçe ders kitaplarındaki metne dayalı anlama sorularının incelenmesi. Ana Dili Eğitimi Dergisi, 7(2), 353-367.

Stice, J. E. (2007). Teaching problem solving. Teachers and Students Sourcebook: Alternative Teaching Methods. http://wwwcsi.unian.it/educa/problemsolving/stice_ps.html erişim tarihi: 22.05.2020

Ünalan, Ş. (2006). Türkçe öğretimi. 3. Baskı, Ankara: Nobel Yayın.

Tabak, G., \& Göçer, A. (2013). 6-8. Sınıflar Türkçe dersi öğretim programının ürün ve süreç odaklı yazma yaklaşımları çerçevesinde değerlendirilmesi. Ahi Evran Üniversitesi Kırşehir Eğitim Fakültesi Dergisi, 14(2).

Taşer, S. (2009). Konuşma eğitimi. İstanbul: Pegasus Yayınları.

Temizkan, M. (2009). Metin türlerine göre okuma eğitimi. Ankara: Nobel Yayın Dağıtım.

Tompkins, G. (2000). Teaching writing: Balancing process and product. 3rd Edition, New Jersey: Prentice - Hall Inc.

Topçuoğlu Ünal, F. ve Özden, M. (2018). Diksiyon ve konuşma eğitimi. 2. Baskı, Ankara: Pegem Akademi.

Weisberg, R. W. (2015). Toward an integrated theory of insight in problem solving. Thinking \& Reasoning, 21(1), 5-39.

Yalçın, A. (2006). Türkçe öğretim yöntemleri: Yeni yaklaşımlar. Ankara: Akçağ Yayınları.

Yıldırım, A. ve Şimşek, H. (2011). Sosyal bilimlerde araştırma yöntemleri. Ankara: Seçkin Yayınları.

Zohar, A., \& Dori, Y. J. (2003). Higher order thinking skills and low-achieving students: Are they mutually exclusive?. The journal of the learning sciences, 12(2), 145-181.

\section{Introduction}

\section{Extended Abstract}

One of the main objectives of Turkish language education is the development of higher-order thinking skills. It is stated that one of the special objectives of the $1^{\text {st }}-8^{\text {th }}$ Grades Turkish Language Education Curriculum which is currently in use is to contribute to the development of higher-order cognitive skills. In the literature, analysis, creating and evaluation skills, which are the last three steps of Bloom taxonomy, are expressed as higher-order thinking skills. However, in some studies, these skills are also defined under different titles such as problem solving, logic, reasoning, reflective thinking, metacognitive thinking, lateral thinking, inductive-deductive thinking...etc. In this study, analytical thinking skill, which is one of the higher-order thinking skills, was discussed. Analytical thinking skills contain the separation of the whole into parts, associating the parts with the whole and with each other.

The problems experienced in teaching higher-order thinking skills in Turkey, can be clearly observed in many studies in literature. Also, it is thought that the most verifiable data to analyze the status of students' analytical thinking skills can be obtained with the PISA reading exam scores. PISA exam results are frequently discussed in Turkey, in general terms. However, these results should be 
considered in terms of the ratio of students who can think at higher levels rather than the cumulative success rate.

It is noteworthy that the ratio of Turkish students who get higher scores in PISA reading exams in age 15 range is low. Indeed, in the 2018 PISA reading test, higher-order thinking skills of the OECD average percentage with level 5 and 6 is $8.6 \%$ while Turkey's ratio is $3.3 \%$. In other words, Turkey have been falling behind the other OECD countries in higher-order thinking.

\section{Method}

This study focuses on how analytical thinking skills can be developed within the context of Turkish language lessons in secondary school. In this research, which was prepared as a review article, basic qualitative research design was used.

In this study, document analysis technique was used as a data collection tool. These documents are as follow;

- academic studies aiming to draw a framework for analytical thinking,

- academic studies linking basic language skills to analytical thinking

- written, visual and audial materials for analytical thinking exercises in four basic language skills.

This study involves association of the mentioned three types of data and interpreting them from analytical thinking perspective. Content analysis method was used for data analysis. Content analysis aims to investigate concepts and relationships that can explain the collected data. In this context, the data are interpreted in a way that the reader can understand by collecting similar data under certain concepts and themes.

\section{Result and Discussion}

As a result of this review and analysis, it was seen that Turkish students' deficiency of analytical thinking skills can be solved with main language skills activities in Turkish language instructions. In reading and listening skills, which can be considered as receptive skills, a deductive process takes place by dividing the whole text into pieces. Therefore, analytical thinking skill is an important skill that can be used in comprehension process. In productive skills, it was seen that analytical thinking can be used in order to elaborate ideas and events and to organize the relations of these details before the text formation phase.

When the reading skill classification of PISA reading exam was examined, it was observed that the skill definitions in the upper levels overlapped largely with analytical thinking. This thinking skill plays a key role in higher-order thinking skills, as it is a preliminary step for evaluation and creation. Therefore, educators should understand the importance of analytical thinking in the education process and develop this skill. Some of the suggestions of this study are as follow;

- In reading and listening skills, analytical thinking can be associated with the implementation of reading strategies.

- As for writing skills, analytical thinking skills that can be used especially for text editing can be adapted to text editing stage of process-based writing and text analyzing stage of genre-based writing practices.

- Finally, analytical thinking skills can be used for understanding and evaluating of media and digital materials. 